\title{
Response of full-scale piles to EPBM tunnelling in London Clay
}

\author{
D. SELEMETAS* and J. R. STANDING $\dagger$
}

\begin{abstract}
The installation and working test performance of four full-scale instrumented driven piles and their subsequent response to twin tunnels constructed below the pile bases are described. One pair was designed to be largely friction piles and the other pair end-bearing. Their locations relative to the new tunnels were carefully chosen to optimise understanding of pile responses at varying offsets from the centre-lines. The site conditions and the greenfield response to earth pressure balance machine tunnelling at the site were described in a companion paper that reported an expanding displacement field around the tunnels rather than the contracting fields usually observed. The field monitoring results indicated that, during construction, zones of influence existed around tunnels, where the ground and piles were subjected to different degrees and senses of relative vertical displacement. Redistributions of load along the pile lengths occurred as the tunnel boring machines approached, passed beneath and continued beyond the pile bases; lateral pile deflections and bending moments were also induced. Based on the results from this field study, implications for the capacity of existing piles (and design of new piles) subjected to tunnelling-induced movements are assessed for cases of expanding and contracting displacement fields.
\end{abstract}

KEYWORDS: field instrumentation; monitoring; piles \& piling; soil/structure interaction; tunnels \& tunnelling

\section{INTRODUCTION}

The subject of tunnelling near piled foundations has received particular attention during construction planning of London's Jubilee Line Extension (JLE), Amsterdam's North-South line, the Channel Tunnel Rail Link (CTRL) and, more recently, London's Crossrail. There is a scarcity of well-documented field studies on this subject. Two notable exceptions are the Heinenoord full-scale trial near Rotterdam (Kaalberg et al., 1999) and the study carried out by Coutts \& Wang (2000), who reported field results from instrumented piles subjected to tunnelling-induced movements as part of the North-East line project in Singapore (see also Pang et al., 2006). In the Heinenoord study, the response of 38 timber piles and 18 concrete piles was monitored during construction of $8.3 \mathrm{~m}$ dia. twin tunnels through both Holocene deposits (layers of soft clay and peat) and Pleistocene dense sand. These field observations indicated that pile settlements can be grouped into three categories depending on the position of the pile toe relative to the tunnel axis (Kaalberg et al., 1999). Jacobsz et al. (2001, 2004) reported results from a number of centrifuge model tests investigating the form of these zones of influence for the case of tunnelling near axially loaded piles driven in dry sand. Similar zones of influence in which pile settlements could be correlated with surface movements were identified from these tests. Other noteworthy model studies include the works of Bezuijen \& Van der Schrier (1994) and Loganathan et al. (2000). The subject has also been studied numerically (Vermeer \& Bonnier, 1991; Mroueh \& Shahrour, 2002) and analytically (Chen et al., 1999).

The research described in this paper was instigated following assessments of piled structures affected by tunnelling

Manuscript received 31 January 2017; revised manuscript accepted 13 June 2017. Published online ahead of print 18 July 2017.

Discussion on this paper closes on 1 February 2018, for further details see p. ii.

Published with permission by the ICE under the CC-BY 4.0 license. (http://creativecommons.org/licenses/by/4.0/)

* Cementation Skanska Limited, Rickmansworth, UK.

$\dagger$ Department of Civil and Environmental Engineering, Imperial

College London, London, UK. works encountered during the construction of London's JLE (Geilen \& Taylor, 2001a, 2001b; Selemetas et al., 2002) and the studies conducted by Kaalberg et al. (1999) and Jacobsz et al. (2001, 2004). Planned construction of the CTRL presented an opportunity to install four full-scale instrumented piles and monitor their response to tunnelling. Details of the site chosen, the ground conditions, tunnelling operations and the greenfield ground response to tunnelling with an earth pressure balance machine (EPBM) tunnel boring machine (TBM) are given by Standing \& Selemetas (2013). Few comprehensive records of the greenfield ground response to EPBM tunnelling in London Clay exist and so this formed an essential component of the study.

\section{FIELD RESEARCH PILES \\ Pile layout}

The four instrumented piles were driven cast-in-situ piles with a nominal diameter of $480 \mathrm{~mm}$. Two of the piles were end-bearing (BC and $\mathrm{BO}$ ) in the Terrace Gravels, with a total length of $8.5 \mathrm{~m}$, while the other two (referred to as friction piles, FC and FO) were $13 \mathrm{~m}$ long and founded in London Clay. Fig. 1 shows the positions of the pairs of end-bearing and friction piles relative to the two tunnels and the soil stratigraphy. Piles BC and FC were installed directly above the up-line tunnel centre-line, while piles BO and FO were offset by $9 \mathrm{~m}$. These pile locations were strategically selected to investigate the existence of zones of influence established by Kaalberg et al. (1999) and Jacobsz et al. (2001).

\section{Pile instrumentation}

The piles were instrumented with $(a)$ vibrating-wire strain gauges to monitor strains and hence obtain the load distribution along the pile, $(b)$ base load cells to provide an independent measure of the load at the base of the piles and (c) electrolevel inclinometers for deriving the deflection profile of the piles (see Fig. 2).

Clusters of four Gage Technique embedment concrete strain gauges, placed at $2 \mathrm{~m}$ intervals along the pile lengths, 

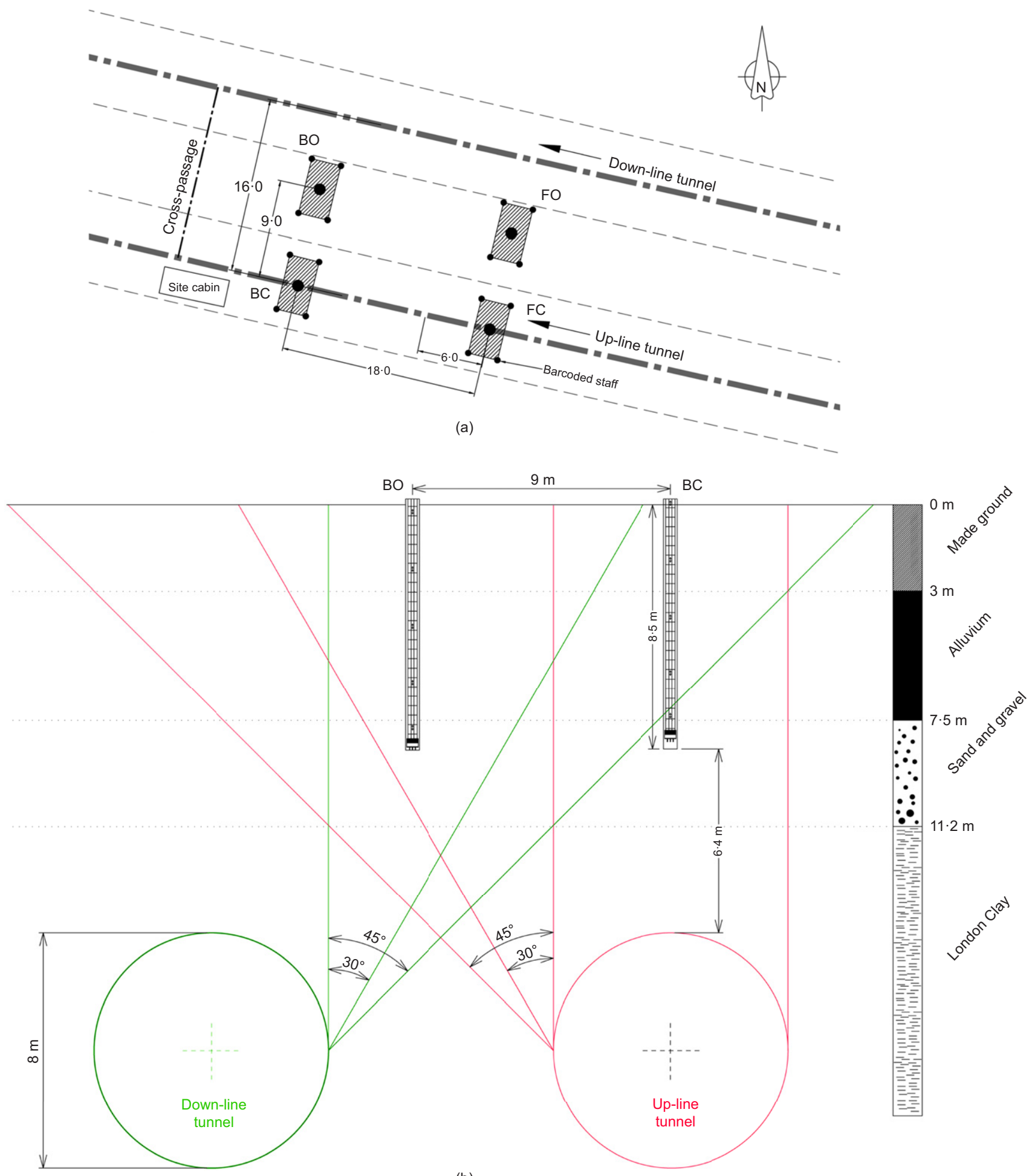

(b)

Fig. 1. Plan view (a) and cross-sections of instrumented piles ((b) and (c)) with reference to twin-tunnel alignment (dimensions in $\mathbf{m})$ (continued on next page)

were attached but not integrally connected to the reinforcing cages of the piles. These devices had a resolution of $1 \mu \varepsilon$ and range of $3000 \mu \varepsilon$. One of the strain gauges at each level was also equipped with a thermistor to record temperature changes. Four strain gauges were used $(a)$ to obtain a good average output and $(b)$ in orthogonal pairs, in line and perpendicular to the TBM drives, to assess bending moments along the pile lengths.

The base load cells adopted, developed at the Building Research Establishment, are described in detail by Price \&
Wardle (1983). The load cells consisted of three $600 \mathrm{kN}$ capacity units for each of the end-bearing piles (BC and $\mathrm{BO}$ ) and four $280 \mathrm{kN}$ units for the friction piles (FC and $\mathrm{FO}$ ) and had a resolution of about $\pm 1 \mathrm{kN}$. The load cells were attached to the bottom of the pile reinforcing cages and each was equipped with a peripheral rubber tube that, once inflated, provided a seal around the cell and a separation boundary to ensure that the entire axial load on the base would pass through the cell unit. Following cage installation, pressure was maintained in the tube until the pile grout had set. 


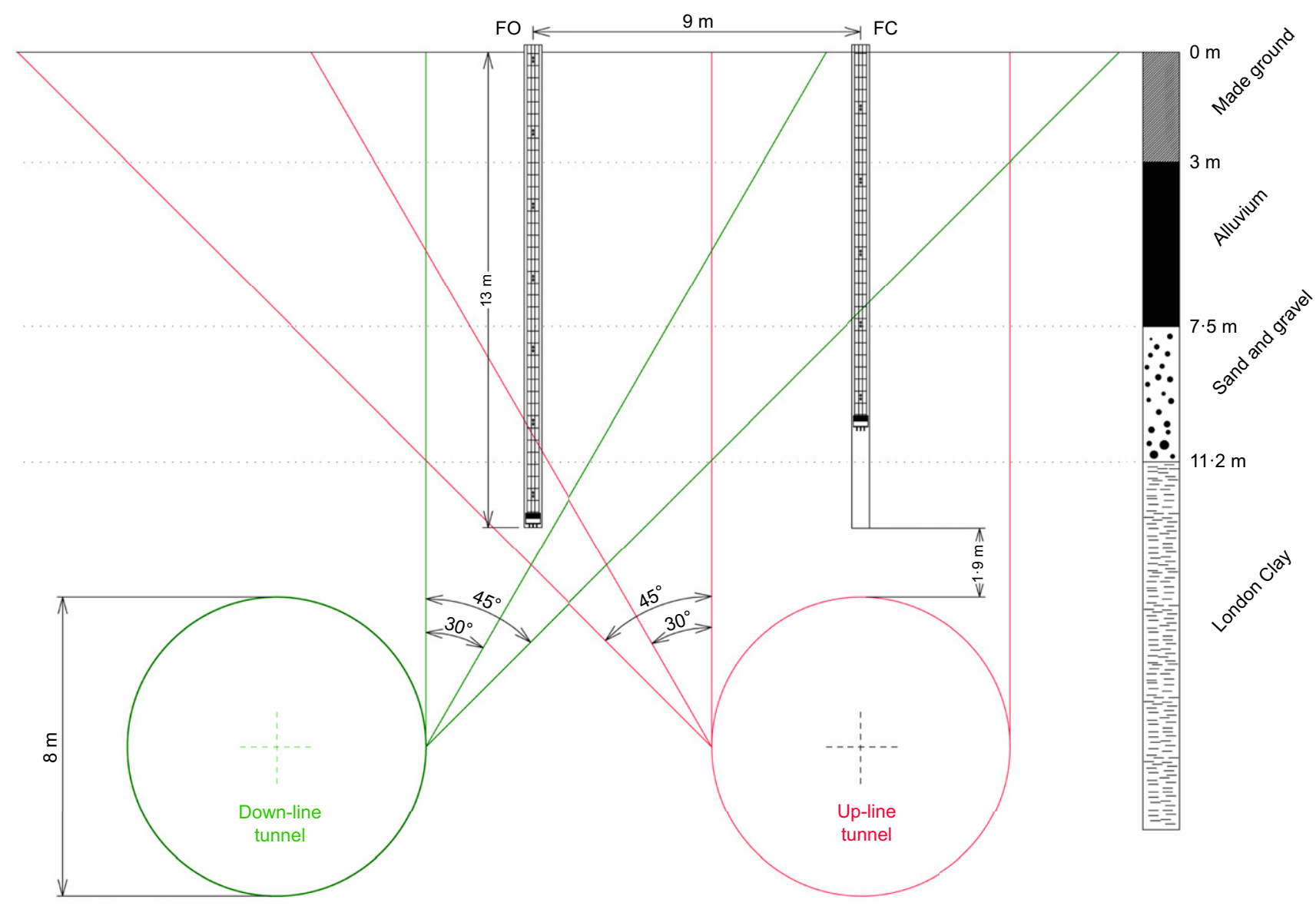

(c)

Fig. 1. Continued

Inclinometer casings were attached to the reinforcing cages, with the keyways orientated in the same sense as the strain gauge pairs; that is, in line with and perpendicular to the TBM drives. After pile construction, pairs of electrolevel devices were installed at $2 \mathrm{~m}$ spacings within the inclinometer casing grouted into the pile: their operation and interpretation were the same as those used for monitoring horizontal ground displacements. The level of each pair of electrolevels corresponded to that of the strain gauges. As well as allowing profiles of tunnelling-induced pile deflections to be determined, the electrolevel inclinometers also allowed bending moments along the pile length to be calculated and corroborated with the strain gauge data.

The displacement of each pile relative to the ground surface was monitored by means of four potentiometric displacement transducers (PDTs) set up at the head of each pile. Two pairs of PDTs were each mounted on a reference beam (one either side of the pile head) that was supported each end on stakes driven a minimum of five pile diameters from each pile, which is greater than the minimum distances recommended in the latest Institution of Civil Engineers (ICE) specification for piling and embedded retaining walls (ICE, 2017). Changes in the absolute level of the reference beams were monitored by precise levelling onto barcoded strips that were permanently attached to the stakes. Thus, each pile had four barcoded strips (at both ends of the two reference beams), which were monitored by a dedicated, permanently set up, precise level for greater stability, accuracy and frequency of measurements. Absolute and relative pile head and ground vertical displacements were determined from this system. Readings from this specific exercise were integrated into the precise levelling runs for the ground monitoring, relating them to the same datum point, on a piled structure about $60 \mathrm{~m}$ from the research site, as described by Standing \& Selemetas (2013).

\section{Pile installation}

The research piles were driven cast-in-situ piles, constructed by top-driving a steel tube fitted with an expendable steel shoe to the required depth using a Junttan PM25 piling rig. The steel tube had an external diameter of $456 \mathrm{~mm}$ and a wall thickness of $20 \mathrm{~mm}$ while the bottom steel shoe was $500 \mathrm{~mm}$ in diameter. The original intention was to place the reinforcing cage, with attached instrumentation, inside the tube after driving and then carefully tremmie in the grout to avoid any damage to the instruments, prior to extracting the tube. However, due to limited clearance between the base load cells and the inner wall of the piling tube, this was not possible, and so the reinforcement cage with instrumentation was inserted following removal of the steel tube, similar to a conventional continuous flight auger pile. In the case of pile FC it was not possible to install the reinforcing cage to the required depth as the grout was setting and was too thick to flow around the base load cell. Consequently, the base load cell in this pile only reached a depth of $10.3 \mathrm{~m}$ rather than the planned depth of $13 \mathrm{~m}$.

The pile reinforcement cage consisted of eight B20 bars with shear links of B8 bars spaced at $300 \mathrm{~mm}$. Additional short lengths of B8 bars were welded between adjacent B20 bars to provide support for the vibrating wire strain gauges (see Fig. 2). The grout used for the piles had a 1:1 sand to cement ratio. Samples of grout taken from piles BC and FC gave average compressive cube strengths of 53.3 and $50 \cdot 5 \mathrm{MPa}$, respectively. 


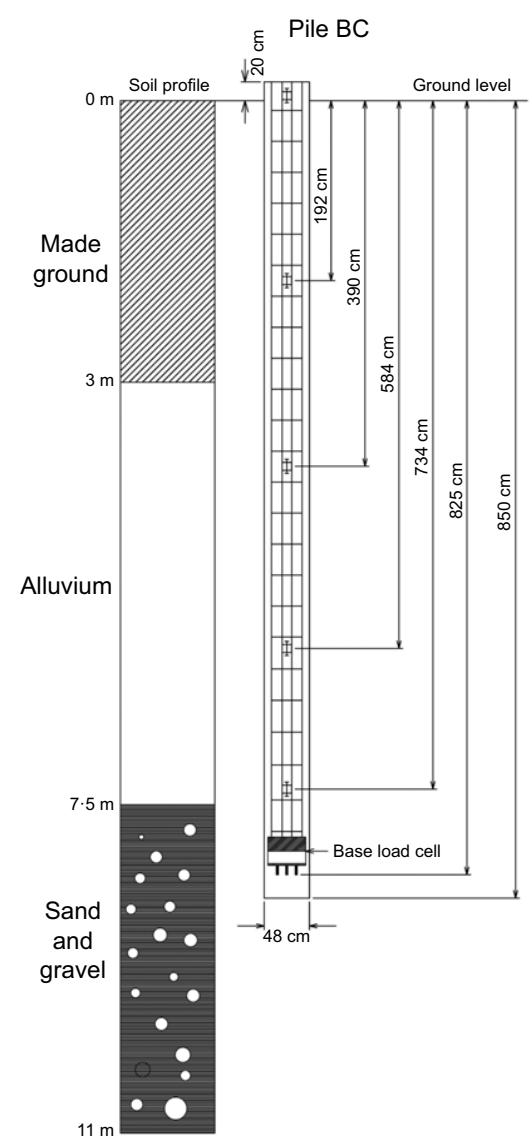

(a)

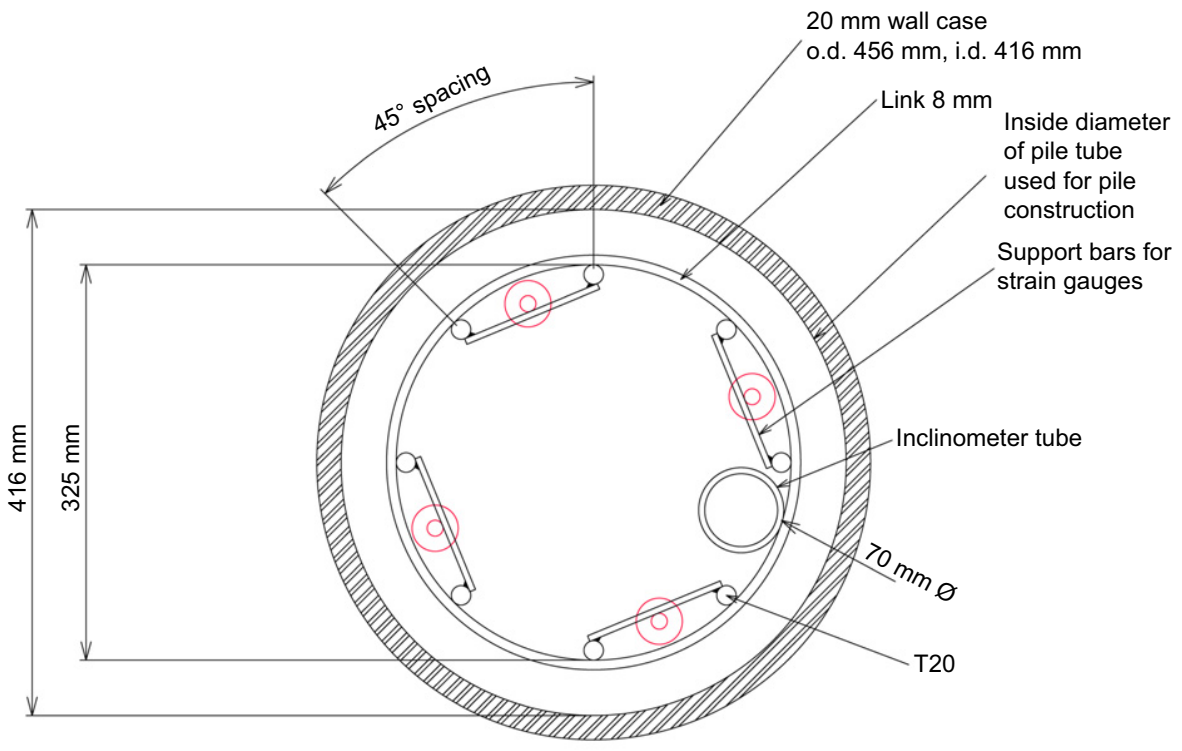

(0) Strain gauge

(b)

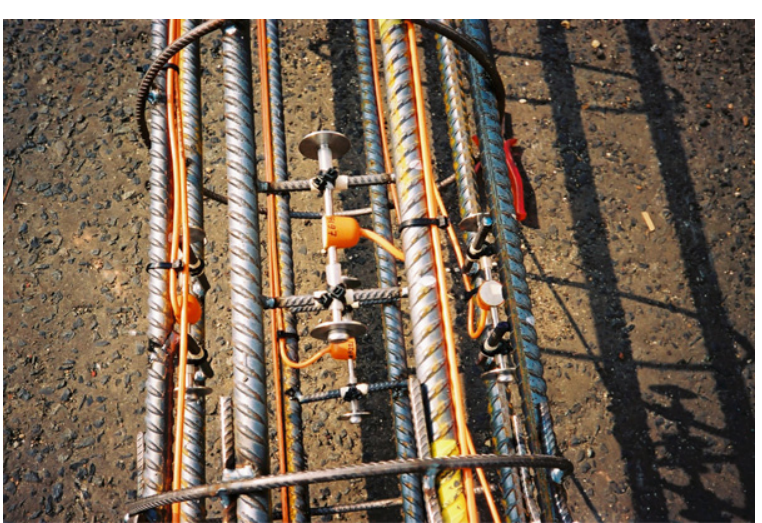

(c)

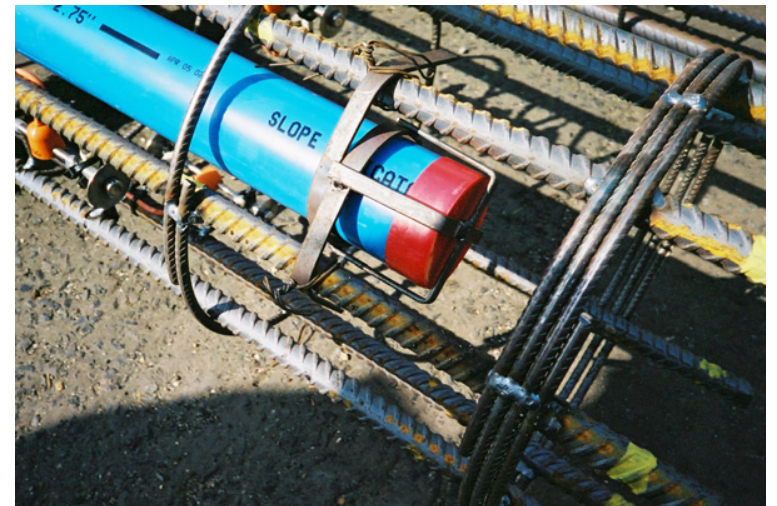

(d)

Fig. 2. Schematic diagram of typical arrangements of strain gauges (a) along length of pile BC and (b) across a pile section and photographs showing attachments to pile reinforcement of (c) strain gauges and (d) inclinometer tubes

\section{PILE RESPONSE DURING INITIAL LOADING}

One month prior to the arrival of the first, up-line, EBPM TBM, all four piles were loaded to approximately $50 \%$ of their estimated ultimate capacity using kentledge reaction platforms. Loads were maintained using load cells to within about $\pm 0.5 \mathrm{kN}$ prior to and during tunnel construction using an automatic computer-controlled system with compressors supplying pressure to air-oil interfaces linked to hydraulic jacks. Each of the end-bearing and friction piles was loaded with $650 \mathrm{kN}$ and $240 \mathrm{kN}$, respectively.

Pile loading involved applying incremental axial head loads $(P)$ with each load increment maintained for a period of $1 \mathrm{~h}$ period. Applied loads and corresponding pile head displacements $\left(S_{\mathrm{p}}\right)$ were recorded at 5 min intervals. Results for the four piles during loading are given in Table 1 (the values of pile settlement represent final values at the end of each load increment, while load values correspond to average values over each increment). This procedure was to simulate a pile-load test in order to obtain load-displacement curves and to estimate pile capacity in terms of shaft capacity and end-bearing.

Pile load-displacement curves for the friction and endbearing piles are shown in Fig. 3 and compared with back-analyses using the CemSet method developed by Fleming (1992). The CemSet parameters used to reproduce the pile test response are summarised in Table 2. The loaddisplacement responses of the friction piles are remarkably similar, albeit the loading range covered is limited. At the end of the final load increment the total pile settlement was less than $1 \mathrm{~mm}$ for both piles. In comparison, the two end-bearing piles show slightly different responses, with pile BC having a stiffer load-settlement relationship. Total pile 
Table 1. Summary of pile load-displacement response during working pile test

\begin{tabular}{l|c|c|c|c|c|c|c}
\hline \multicolumn{2}{l|}{ Pile FO } & \multicolumn{2}{c|}{ Pile FC } & \multicolumn{2}{c}{ Pile BO } & \multicolumn{2}{c}{ Pile BC } \\
\hline $\begin{array}{l}P: \\
\mathrm{kN}\end{array}$ & $\begin{array}{c}S_{\mathrm{p}}: \\
\mathrm{mm}\end{array}$ & $\begin{array}{c}P: \\
\mathrm{kN}\end{array}$ & $\begin{array}{c}S_{\mathrm{p}}: \\
\mathrm{mm}\end{array}$ & $\begin{array}{c}P: \\
\mathrm{kN}\end{array}$ & $\begin{array}{c}S_{\mathrm{p}}: \\
\mathrm{mm}\end{array}$ & $\begin{array}{c}P: \\
\mathrm{kN}\end{array}$ & $\begin{array}{c}S_{\mathrm{p}}: \\
\mathrm{mm}\end{array}$ \\
\hline 0 & 0 & 0 & 0 & 0 & 0 & 0 & 0 \\
40 & $-0 \cdot 01$ & 41 & $-0 \cdot 03$ & 150 & $-0 \cdot 29$ & 151 & $-0 \cdot 38$ \\
81 & $-0 \cdot 08$ & 81 & $-0 \cdot 06$ & 258 & $-0 \cdot 84$ & 251 & $-0 \cdot 84$ \\
120 & $-0 \cdot 24$ & 121 & $-0 \cdot 24$ & 352 & $-1 \cdot 46$ & 351 & $-1 \cdot 41$ \\
160 & $-0 \cdot 34$ & 161 & $-0 \cdot 34$ & 453 & $-2 \cdot 38$ & 451 & $-2 \cdot 06$ \\
200 & $-0 \cdot 48$ & 200 & $-0 \cdot 48$ & 553 & $-3 \cdot 35$ & 550 & $-2 \cdot 78$ \\
240 & $-0 \cdot 66$ & 241 & $-0 \cdot 65$ & 652 & $-4 \cdot 60$ & 651 & $-3 \cdot 80$ \\
\hline
\end{tabular}

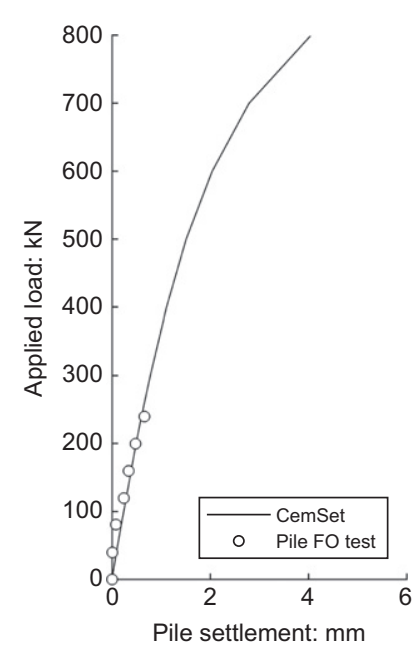

(a)

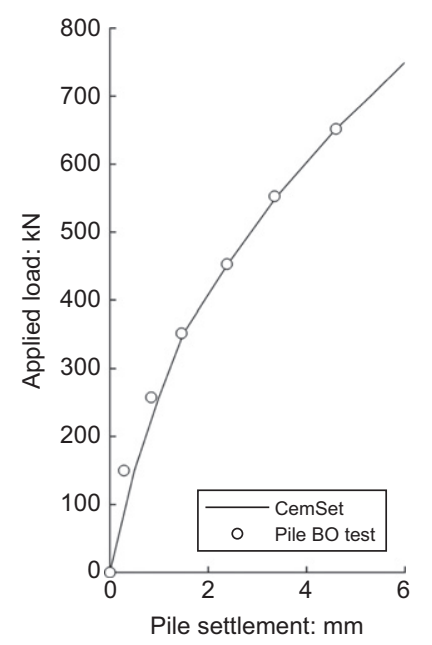

(c)

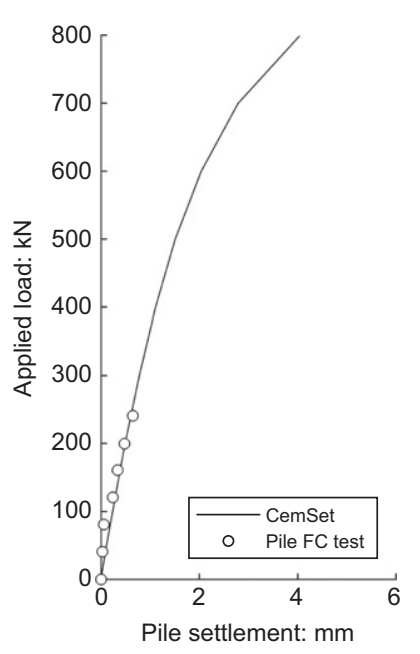

(b)

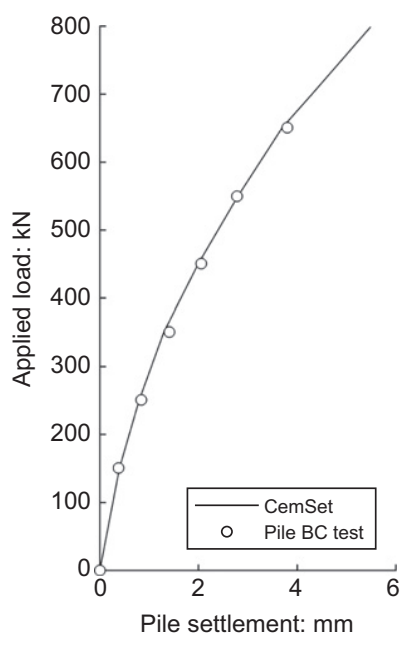

(d)
Fig. 3. Pile load-test settlement results compared with CemSet model predictions: (a) pile $\mathrm{FO}$; (b) pile $\mathrm{FC}$; (c) pile $\mathrm{BO}$; (d) pile $\mathrm{BC}$

settlements were $4.6 \mathrm{~mm}$ for pile $\mathrm{BO}$ and $3.8 \mathrm{~mm}$ for pile $\mathrm{BC}$. The final values of pile settlement indicate that the friction piles FC and FO mobilised a small portion of their total shaft friction along their lengths while the end-bearing piles $\mathrm{BC}$ and $\mathrm{BO}$ mobilised their full shaft friction during the pile test. The stiffer response of pile $\mathrm{BC}$ can be attributed to the presence of denser Terrace Gravels below the base of this pile. Tube-driving records during pile installation, in the form of number of blows per $0.25 \mathrm{~m}$ depth, indicate that this stratum was denser at the positions of piles BC and FC compared with the locations of piles BO and FO (Selemetas, 2005).
Pile stiffness and load distribution with depth

Distributions of axial load along pile lengths are determined indirectly from measurements of strain. The measured strain at each pile level is multiplied by the pile crosssectional area and the pile stiffness to obtain the resulting axial load at this level. Pile stiffness, $E_{\mathrm{p}}$, is calculated from the ratio of applied stress over average strain measured near the top of each pile. As the level of the upper strain gauges was very close to the ground surface $(<0.25 \mathrm{~m}$ for piles FO, BO and $\mathrm{BC}$ ), it was considered that pile shaft friction should be negligible and the load acting at this level was assumed to be equal to the applied load at the head of each pile. This was not the case for pile FC, with strain gauges $1.5 \mathrm{~m}$ below the ground surface.

The development of back-calculated pile stiffness for piles FO, BO and BC with time (starting immediately after the end of the final pile-loading stage (16 January 2003)) is shown in Fig. 4(a). The stiffness of pile FC is assumed to be equal to that of pile FO. The stiffness of the three piles follows the form of an exponential function with a maximum value of $E_{\mathrm{p}(\max )}=23.4 \mathrm{GPa} 1$ day after the final pile-loading stage, reducing to approximately $75 \%$ of $E_{\mathrm{p}(\max )}$ over the next 68 days (Fig. 4(b)). The power curve shown in Fig. 4(b) is a normalised best-fit curve for the three back-calculated curves in Fig. 4(a) following regression analysis. The reduction of pile stiffness over time is due to time-dependent creep strains occurring in each pile. The maximum back-calculated value $\left(E_{\mathrm{p}(\max )}\right)$ agrees well with values that would be obtained from code recommendations and best industry practice documents by making an allowance for creep effects, for example BS EN 1992-1-1 (BSI, 2004).

The load transfers along the four piles at the end of each loading stage, assuming zero strain at the onset of loading (i.e. no initial residual strains), are shown in Fig. 5. During pile loading, a significant amount of shaft resistance was mobilised for all piles within the made ground (i.e. within the first $3 \mathrm{~m}$ depth), while little or no shaft friction was generated in the alluvium. This is particularly evident in pile $\mathrm{BC}$ for which the axial strains at levels below $-3 \mathrm{~m}$ were almost identical, indicating that little or no shaft friction was mobilised along the length of the pile in the alluvium, which extends to $7 \cdot 5-8 \mathrm{~m}$. Friction piles FC and FO transferred most of their load through shaft friction, with pile FO carrying only $10 \%$ of the applied load in end-bearing. Pile BO also exhibited significant shaft friction take-up, carrying only $40 \%$ of the final applied load at its base. In comparison, pile $\mathrm{BC}$ behaves more like an end-bearing pile, carrying about $60 \%$ of the total applied load in end-bearing. The almost parallel load transfer profiles in Fig. 5 indicate that the shorter piles BC and BO mobilised their shaft capacity during pile loading, unlike the longer friction piles which had some reserve shaft capacity.

Prior to loading, the piles were subjected to unintentional 'pre-loading' effects from the initial placement of kentledge on the ground (i.e. before its load was transferred to the piles). Surface settlements from this temporary kentledge load were presented and discussed by Standing \& Selemetas (2013). Following installation of a driven pile, negative shaft friction develops along the length of the pile where the consolidating soil is moving down relative to the pile, giving rise to a locked-in 'residual' load (see Fellenius, 2004). If it is considered that there is no residual load in the pile and the load induced in the pile during static pile testing is monitored, this load distribution is referred to as 'apparent' load. The 'actual' load distribution is simply the superposition of the 'residual' and the 'apparent' load distributions. The residual loads measured in the four piles prior to loading are presented in Fig. 6 along with the apparent axial load distribution after pile loading (ignoring any residual 
Table 2. Summary of CemSet parameters used to back-analyse pile test response (for all piles, shaft flexibility factor $M_{\mathrm{s}}=0 \cdot 0015$ and friction centroid $=0 \cdot 45$ )

\begin{tabular}{|c|c|c|c|c|c|c|c|}
\hline & $\begin{array}{c}\text { Shaft } \\
\text { diameter: } \mathrm{mm}\end{array}$ & $\begin{array}{c}\text { Base } \\
\text { diameter: } \mathrm{mm}\end{array}$ & $\begin{array}{l}\text { Shaft free } \\
\text { length: } \mathrm{m}\end{array}$ & $\begin{array}{l}\text { Shaft friction } \\
\text { length: } \mathrm{m}\end{array}$ & $\begin{array}{l}\text { Ultimate shaft } \\
\text { friction: } \mathrm{kN}\end{array}$ & $\begin{array}{c}\text { Ultimate } \\
\text { end-bearing: } \mathrm{kN}\end{array}$ & $\begin{array}{l}\text { Soil modulus at } \\
\text { pile base, } E_{\mathrm{b}}: \mathrm{kPa}\end{array}$ \\
\hline Pile FO & 480 & 500 & $4 \cdot 5$ & $8 \cdot 5$ & 960 & 140 & 20000 \\
\hline Pile FC & 480 & 500 & $4 \cdot 5$ & $8 \cdot 5$ & 960 & 140 & 20000 \\
\hline Pile BO & 480 & 500 & $4 \cdot 5$ & $4 \cdot 0$ & 400 & 1963 & 150000 \\
\hline Pile BC & 480 & 500 & $4 \cdot 5$ & $4 \cdot 0$ & 430 & 1963 & 120000 \\
\hline
\end{tabular}

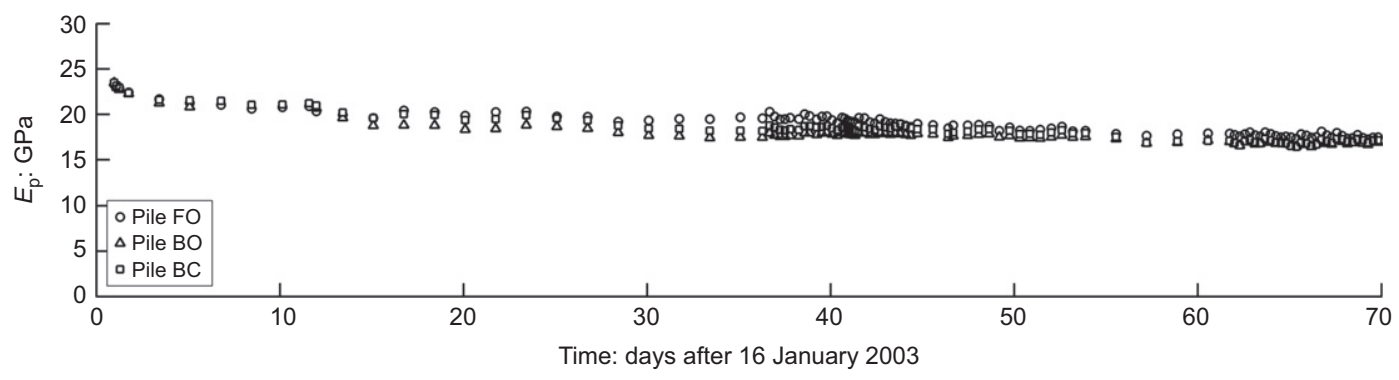

(a)

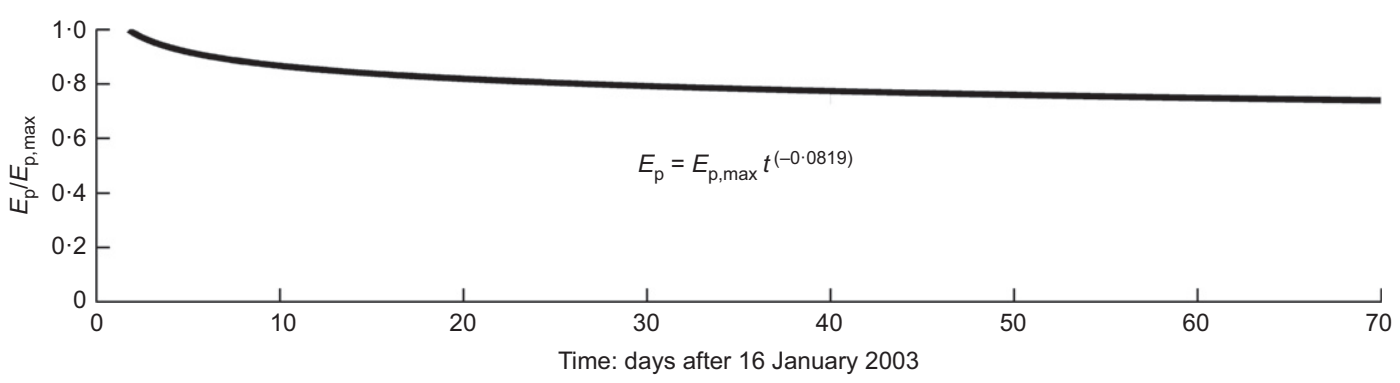

(b)

Fig. 4. Relationship of apparent pile stiffness degradation with time: (a) back-calculated values from measurements; (b) normalised best-fit curve

load) and the actual load distribution in the piles obtained by superimposing the curves of residual and apparent load. The apparent axial load distributions are identical to the final load transfer curves shown in Fig. 5. The actual load distribution curves at the end of pile loading describe a more gradual transfer of load from the top of each pile to its base. Failure to account for residual loads generated in the piles would result in an overestimation of pile shaft friction and an underestimation of pile base load.

\section{PILE RESPONSE TO TUNNELLING \\ Pile settlement due to tunnelling}

In reviewing tunnelling-induced pile settlements, it is useful to compare tunnelling-induced pile head displacements with those of the surrounding ground surface. Emphasis is placed on the ratio of absolute pile head displacement, $S_{\mathrm{p}}$, to the surrounding ground surface vertical displacement, $S_{\mathrm{g}}$, denoted by $R$ (i.e. $R=S_{\mathrm{p}} / S_{\mathrm{g}}$ ). Thus, $R$ values greater than unity indicate that the pile head has settled more than the ground surface, giving rise to differential pile settlement $\left(=S_{\mathrm{g}}-S_{\mathrm{p}}\right.$, a negative value). Conversely, $R$ values less than unity imply differential pile heave ( $=S_{\mathrm{g}}-S_{\mathrm{p}}$, a positive value) relative to the ground.

Up-line tunnel: pile vertical displacements. Figure 7(a) shows the variations in applied load at the head of pile FC (above the centre-line of the up-line tunnel) with time and the development of pile vertical displacement with time compared with the corresponding ground movements during construction of the up-line tunnel; the advancement rate of the TBM showing the position of the EPBM face relative to pile FC is also plotted. Standing \& Selemetas (2013) have described and linked the ground response to the approach and passing of the TBM. During passage of the EPBM, the applied load at the head of the pile exhibited small variations due to thermal effects and sensitivity to pile movements: maximum changes were less than $20 \mathrm{kN}$. Initially, the ground and pile heaved by about $2 \mathrm{~mm}$ as the face approached, resulting in small pile-load increases. Immediately after the EPBM face passed underneath the pile, both the pile and the ground settled, with the pile settling more than the ground $\left(S_{\mathrm{p}}=4.0 \mathrm{~mm} ; S_{\mathrm{g}}=1.7 \mathrm{~mm}\right)$, giving $R>1$ and resulting in a reduction in pile load (at about 38 days). A small degree of further heave then occurred from tail-skin grouting. Following the passage of the shield and the tail-grouting phase, both the pile and the ground showed small sudden settlement (at about 42 days) when the TBM started again (after a delay of $41 \mathrm{~h}$ as it was necessary to rebuild a damaged ring) followed by gradual tunnelling-induced consolidation (about $4 \mathrm{~mm}$ over the course of 23 days).

Construction of the up-line tunnel did not significantly influence pile FO (at $9 \mathrm{~m}$ offset from the tunnel centre-line), as shown in Fig. 7(b). The pile followed the pattern of ground surface displacement during and following the passage of the up-line TBM; that is, $R=1$ for most practical purposes. The magnitudes of initial heave and final settlement for pile FO were less than those of pile FC. The reasons for the applied 


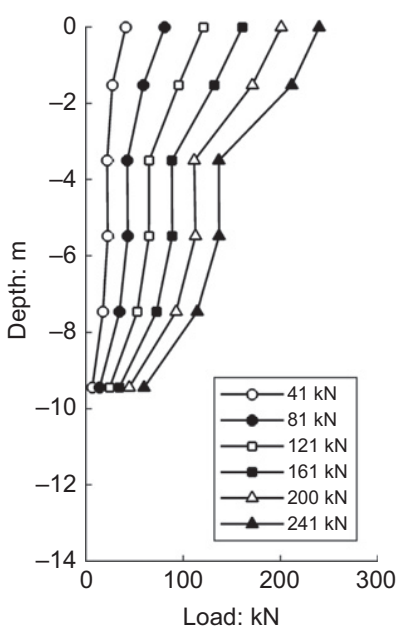

(a)

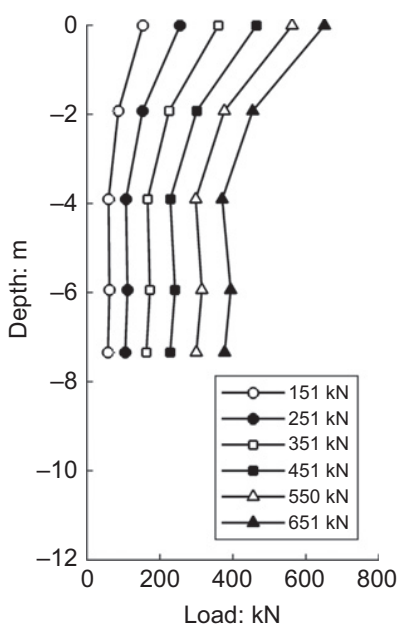

(c)

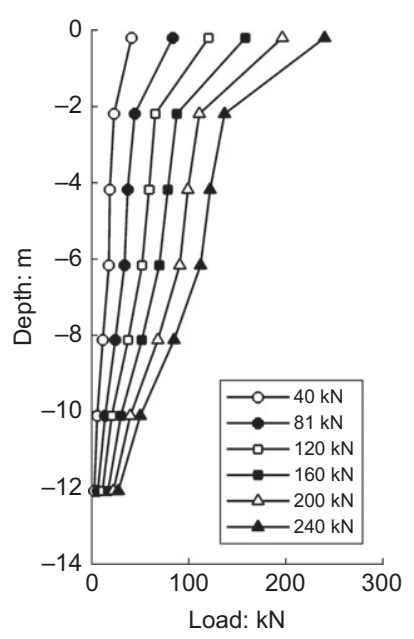

(b)

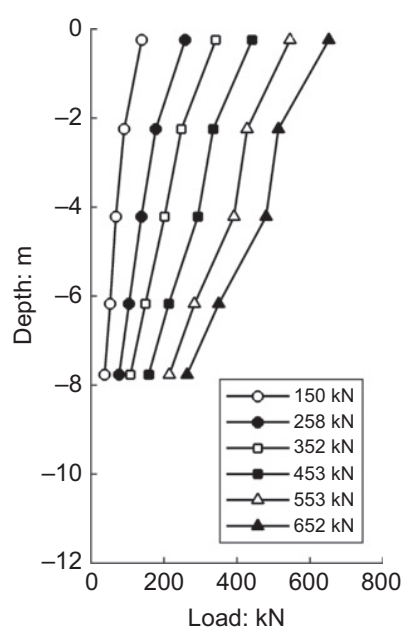

(d)
Fig. 5. Pile-load transfer curves during head loading: (a) pile FC; (b) pile $\mathrm{FO}$; (c) pile $\mathrm{BC}$; (d) pile $\mathrm{BO}$ (the legend shows applied head loads)

pile load increasing to approximately $260 \mathrm{kN}$ (from the target control value of $240 \mathrm{kN}$ ) are not known.

End-bearing pile $\mathrm{BC}$ experienced a similar response to the centre-line friction pile FC, as shown in Fig. 7(c). Initially, the pile heaved by $0.5 \mathrm{~mm}$ with the arrival of the EPBM face (a smaller heave than that of pile FC because of the greater distance between the pile toe and tunnel crown, $6.35 \mathrm{~m}$ as opposed to $1.85 \mathrm{~m}$ ). The toe level of pile $\mathrm{BC}$ is just within the zone of ground heave reported by Standing \& Selemetas (2013). During this initial heave, the load applied at the top of pile BC increased rapidly from $660 \mathrm{kN}$ to about $700 \mathrm{kN}$. The applied load was quickly restored to its target value of $650 \mathrm{kN}$, but continued to show high sensitivity during the passage of the EPBM face beneath the pile. The $41 \mathrm{~h}$ delay of the EPBM occurred when its face was almost directly beneath pile $\mathrm{BC}$ (which is $18 \mathrm{~m}$ from pile $\mathrm{FC}$, as shown in Fig. 1). During this period, the ground and the pile settled gently but once the EPBM started progressing again the rate of pile settlement accelerated rapidly and the applied load at the top of the pile suddenly increased to $750 \mathrm{kN}$. At this time, pile $\mathrm{BC}$ settled more than pile $\mathrm{FC}$ at the same stage $(6.5 \mathrm{~mm}$ compared with $4 \mathrm{~mm}$ ) because of the much greater load acting on it. The applied load was quickly restored to its original value but subsequently increased rapidly to $800 \mathrm{kN}$, again during tail-skin grouting. Over time, the pile and the ground continued to settle due to consolidation, reaching

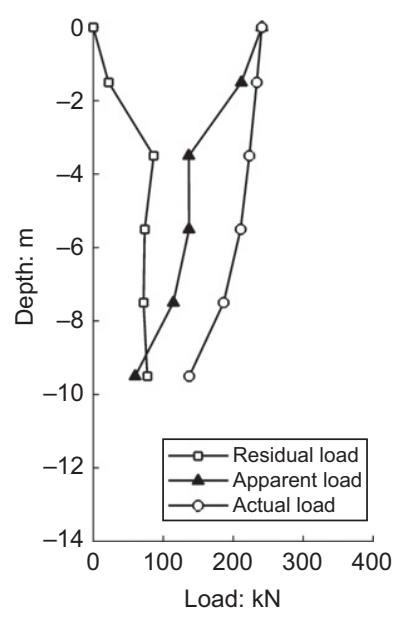

(a)

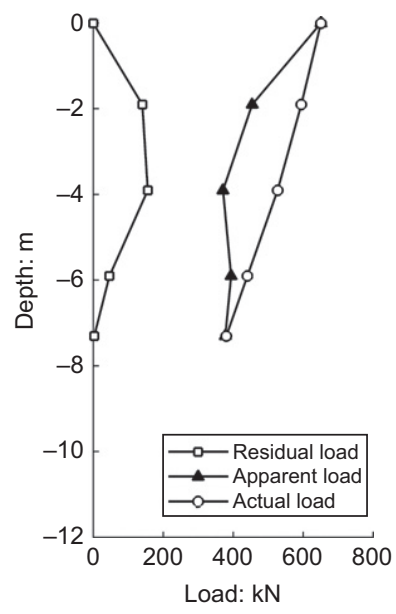

(c)

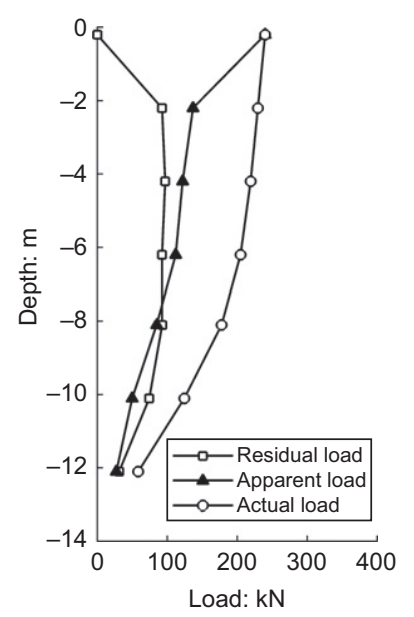

(b)

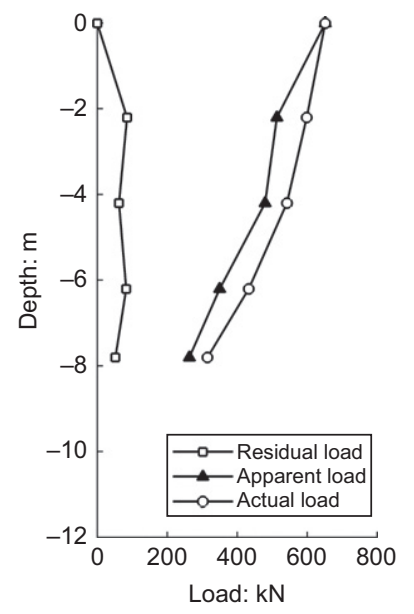

(d)
Fig. 6. Pile-load distribution curves including residual load effects at the end of pile loading (16 January 2003): (a) pile FC; (b) pile FO; (c) pile $\mathrm{BC}$; (d) pile $\mathrm{BO}$

values of $S_{\mathrm{p}}=10 \mathrm{~mm}$ and $S_{\mathrm{g}}=7 \mathrm{~mm} 20$ days after the passage of the shield beneath the pile. The sudden heave shown by pile $\mathrm{BC}$ on day 49 corresponds to a temporary reduction in the load at the top of the pile.

The response of offset pile BO ( $9 \mathrm{~m}$ from the up-line tunnel centre-line) was similar to that of pile FO (Fig. 7(d)), with greatly reduced displacements and very small load changes. Pile BO and the surrounding ground experienced slight heave followed by gradual settlement after the passage of the TBM, with $R$ values equal to 1 . The applied load on pile BO was well controlled during tunnel construction and there were no signs of influence from the events causing construction delays.

Down-line tunnel: pile vertical displacements. Incremental vertical displacements and applied loads for the friction and end-bearing piles during passage of the down-line tunnel are shown in Fig. 8. In this case, piles FO and BO are offset by $7 \mathrm{~m}$ from the centre-line of the down-line tunnel (which is a similar offset to that from the up-line tunnel $(9 \mathrm{~m}))$, while piles $\mathrm{FC}$ and $\mathrm{BC}$ are at an offset of $16 \mathrm{~m}$. The response of piles FO and BO was almost identical to that of the surrounding ground during and following the passage of the down-line EPBM. This correlates well with their response to the up-line tunnel construction for which they were at a similar offset. Both piles showed a short-term settlement 

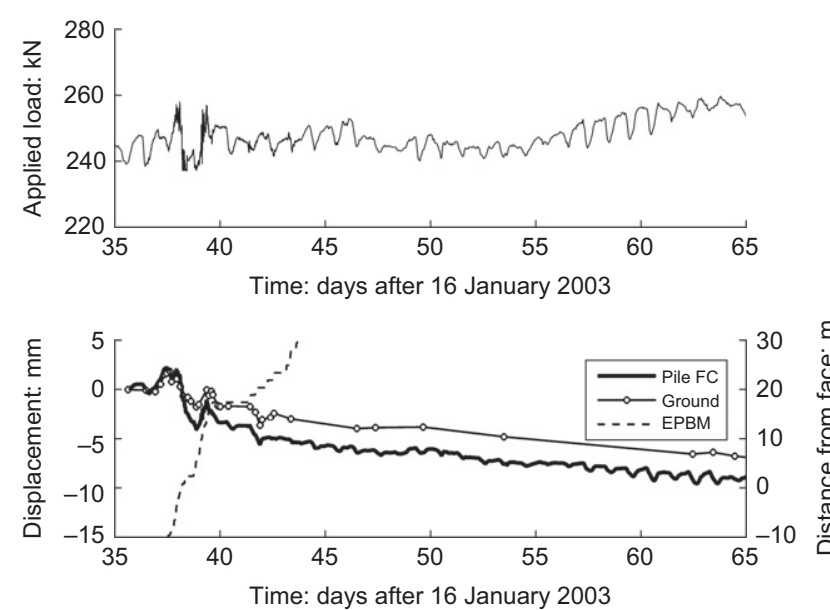

(a)
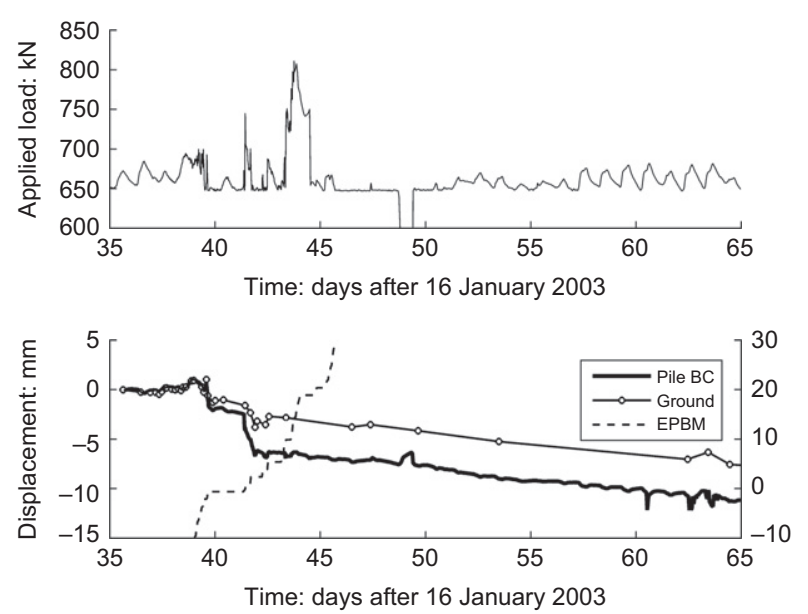

(c)
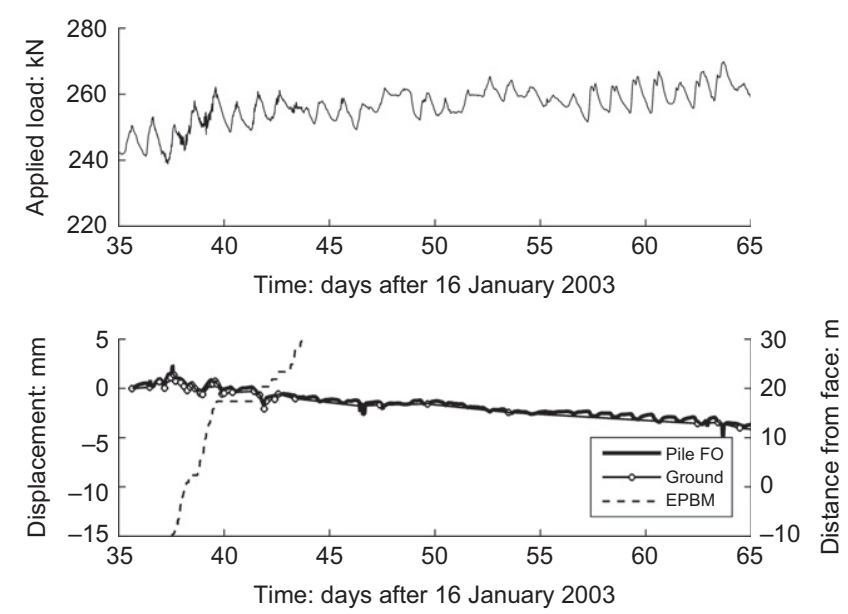

(b)
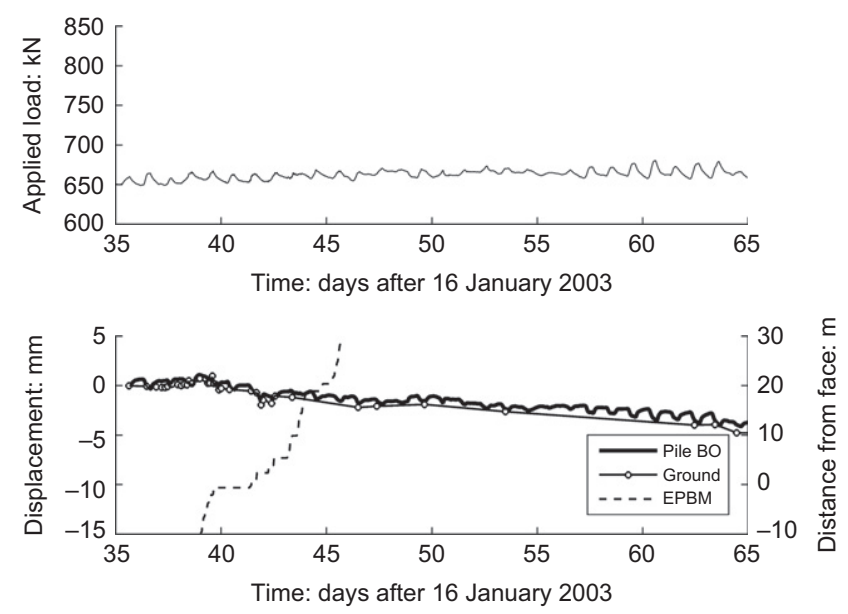

(d)

Fig. 7. Development of applied pile load and pile head displacement compared with the surrounding ground displacement during passage of the up-line TBM: (a) pile FC; (b) pile FO; (c) pile BC; (d) pile BO

of approximately $5 \mathrm{~mm}$ (Figs 8(b) and (d)), with negligible initial heave, followed by consolidation settlement of $5 \mathrm{~mm}$ over a period of 10 days. In comparison, piles $\mathrm{FC}$ and $\mathrm{BC}$, at a greater offset, experienced negligible or only slight settlement due to tunnelling (Figs 8(a) and (c)). Consolidation settlements of the ground surrounding them were slightly greater, imposing a small degree of negative shaft friction on these piles.

Differential pile displacements. Pile head displacements in the form of differential pile displacements (settlement and heave) against distance from the face of the tunnelling shield are presented in Fig. 9 for the up-line TBM drive. The piles show clear trends in behaviour during the various construction phases. Pile FC initially experienced slight differential heave with the TBM face about $4 \mathrm{~m}$ away $(y=-4 \mathrm{~m})$ followed by differential settlement just before the TBM face passed beneath the pile. This initial heave is hardly surprising in view of the clearance of only $1.9 \mathrm{~m}$ between the pile toe and the tunnel crown and the high EPBM pressures applied at the face of the excavation. Pile BC, with a clearance of $6.4 \mathrm{~m}$ from the tunnel crown, exhibited no differential heave and only slight differential settlement at a distance of about $y=-2 \mathrm{~m}$ from the TBM face. These responses indicate that EPBM tunnelling is very efficient in minimising differential displacements ahead of the face but a sudden increase occurs once the TBM face is directly beneath the pile.
As the TBM face progressed beyond piles $\mathrm{FC}$ and $\mathrm{BC}$, they settled more than the ground, over a distance of up to $10 \mathrm{~m}$, corresponding to the length of the EPBM shield. Measurements from the pile instrumentation indicate that, during this stage, both piles experienced a reduction in their base load which was compensated by a mobilisation of reserve shaft capacity, hence resulting in differential pile settlement relative to the ground. In particular, pile FC (of length $13 \mathrm{~m}$ ) experienced $2.5 \mathrm{~mm}$ of differential pile settlement compared with $4 \mathrm{~mm}$ for pile BC (of length $8.5 \mathrm{~m})$. This difference can be partly attributed to the different loads applied to each pile and the difference in pile lengths (a longer pile settling less than a shorter pile to mobilise the same amount of shaft capacity). The results suggest that the phase when the shield passes beneath the pile is the most critical in terms of the impact on adjacent structures, as it causes the greatest differential displacements.

Tail-skin grouting was performed following the passage of the shield to fill the void between the most recently placed segmental ring and the ground. This caused a slight differential heave of about $0.5 \mathrm{~mm}$ for piles $\mathrm{FC}$ and $\mathrm{BC}$ (at just beyond $y=10 \mathrm{~m}$ ). Subsequently, the piles experienced small differential settlements, the rate of which rapidly diminished.

During construction of the down-line tunnel, piles FO and $\mathrm{BO}$ (at an offset of $7 \mathrm{~m}$ from the tunnel centre-line) experienced negligible differential pile settlements (i.e. $R \sim 1$ ). In the case of piles FC and BC (at an offset of $16 \mathrm{~m}$ ), the 

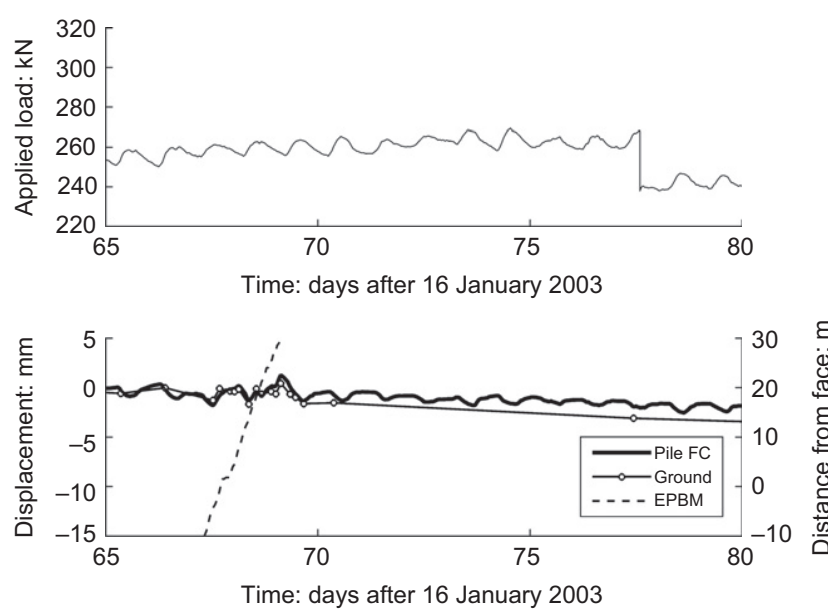

(a)
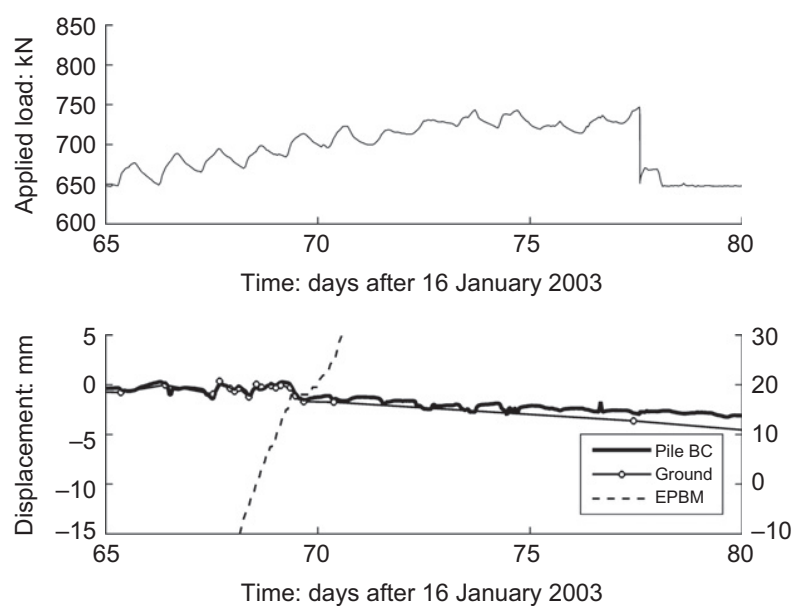

(c)
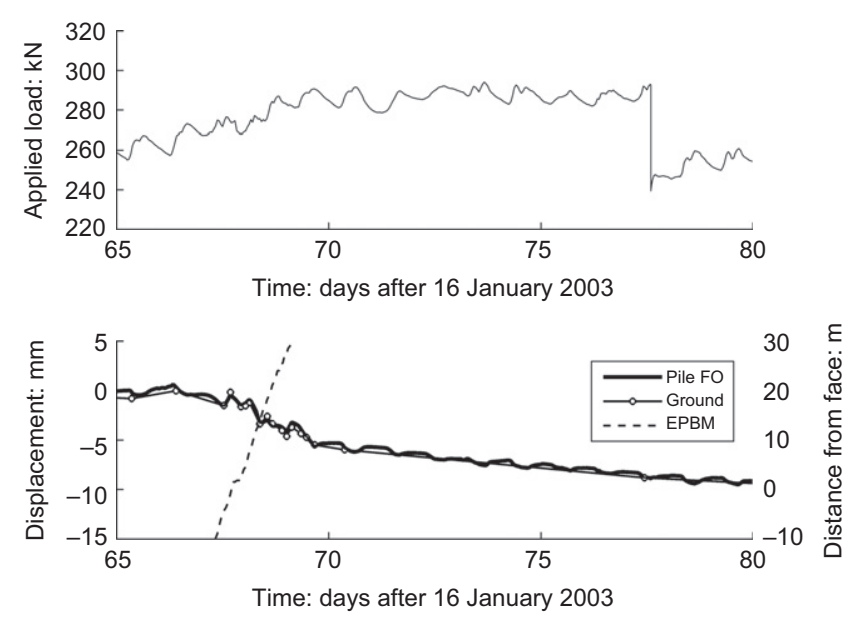

(b)
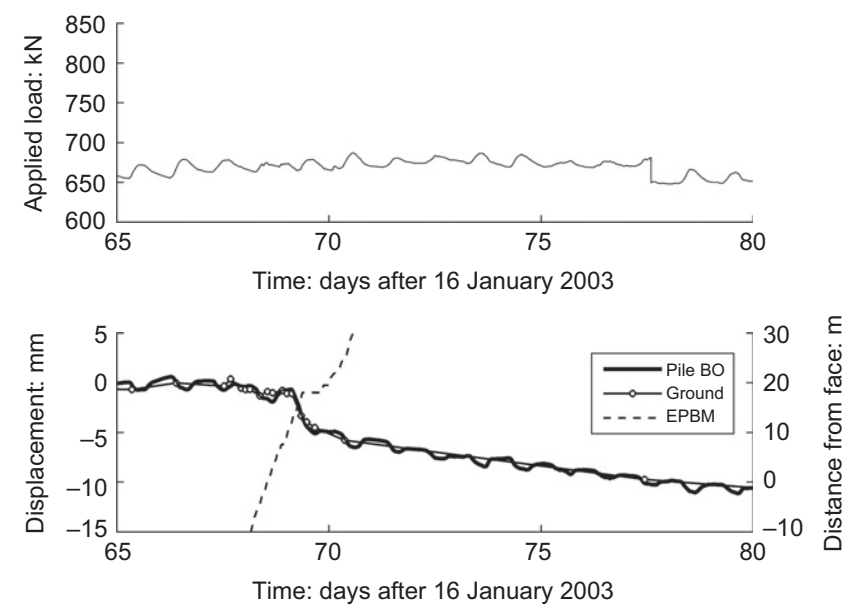

(d)

Fig. 8. Development of applied pile load and pile head displacement compared with the surrounding ground displacement during passage of the down-line TBM: (a) pile FC; (b) pile FO; (c) pile BC; (d) pile BO

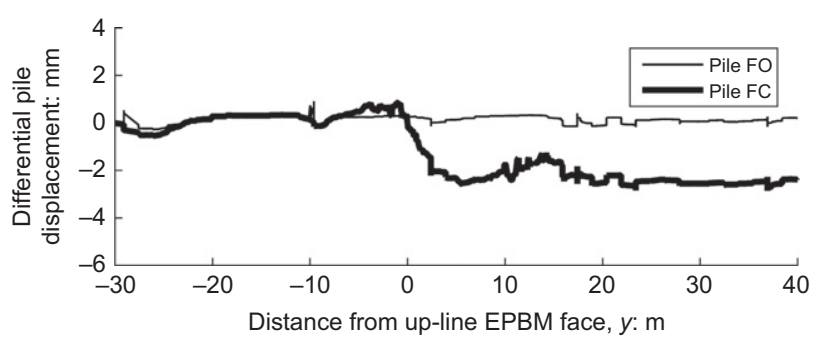

(a)

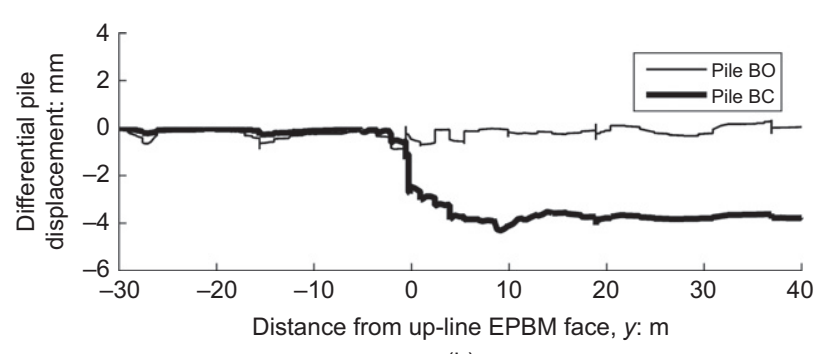

(b)

Fig. 9. Development of differential pile displacements during approach and passage of up-line EPBM TBM drive in different phases of EPBM operation: (a) piles FC and FO; (b) piles BC and BO

surrounding ground settled slightly more than the piles (i.e. differential pile heave with $R<1$ ), implying that negative shaft friction was induced along the length of these piles.
Axial load response due to tunnelling

Axial loads within the piles were assessed using the values determined from the strain gauge clusters positioned along their lengths. Near the base of each pile, the pattern of axial load change measured from the strain gauge readings was of similar form to that from the base load cell measurements. However, in most cases, the absolute magnitudes of loads registered from the base load cells were less than those determined from the strain gauge clusters. This is thought to be due to the peripheral rubber tube around the base load cell not expanding fully during installation and grouting, resulting in some load bypassing the base load cell unit. The base load cell results are therefore not presented here.

Up-line tunnel: pile-load distributions. Axial loads for each strain gauge cluster position along the length of pile FC during construction of the up-line tunnel are plotted against time in Fig. 10; the distance of the EPBM face from the pile is also shown. The load plotted at a depth of $z=0 \mathrm{~m}$ (Fig. 10(a)) corresponds to the applied load at the top of the pile, which remained reasonably constant at $240 \mathrm{kN}$. Prior to the TBM influencing the pile, the load applied at the top of the pile can be seen to reduce with depth (i.e. at each cluster point) as it was distributed to the ground by way of shaft friction. Key points during tunnel construction $(\mathrm{O}, \mathrm{A}, \mathrm{B}, \mathrm{C}$ and D) can be identified for each of the traces: they are only marked on Fig. 10(d). Point O represents the initial 


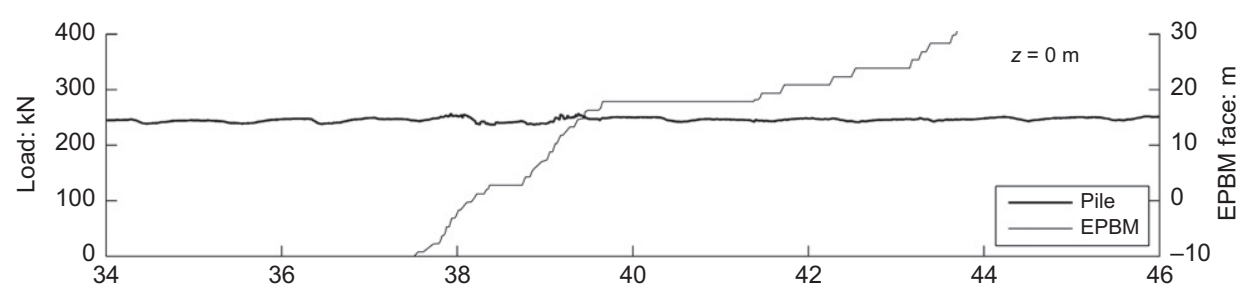

(a)

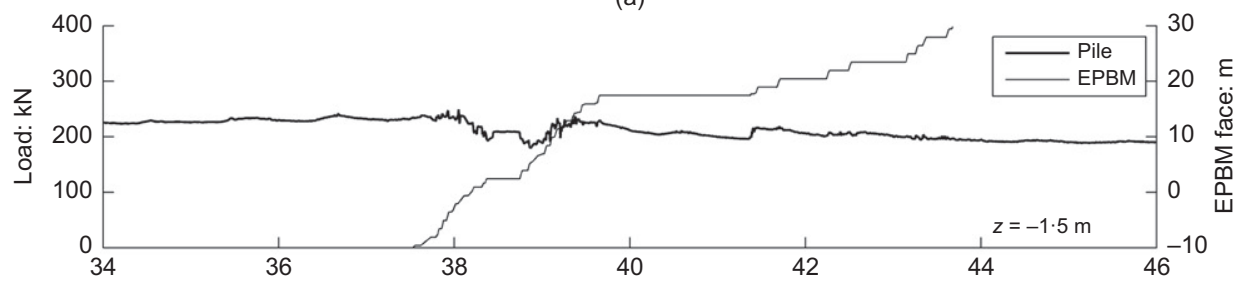

(b)

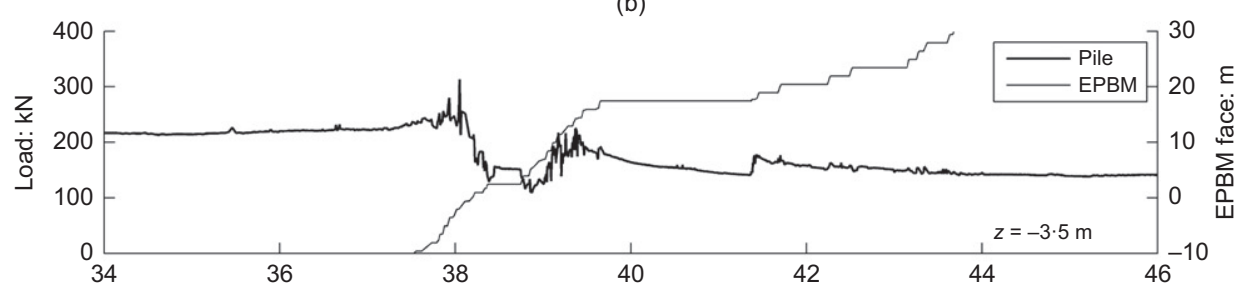

(c)

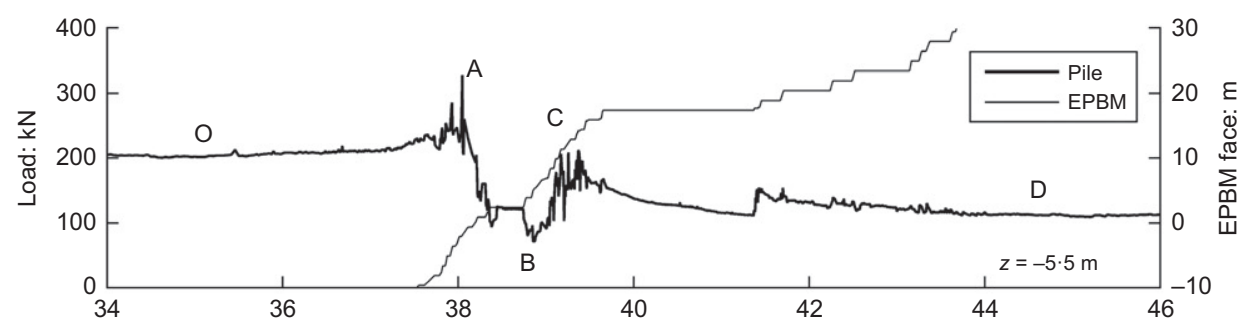

(d)

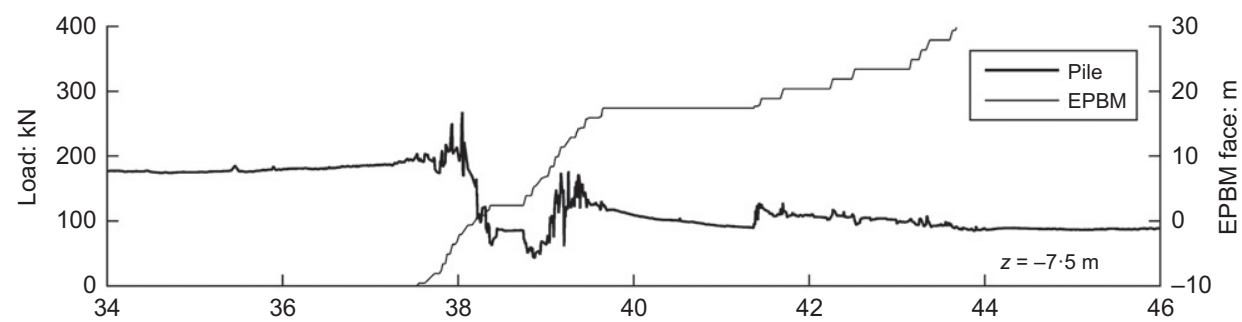

(e)

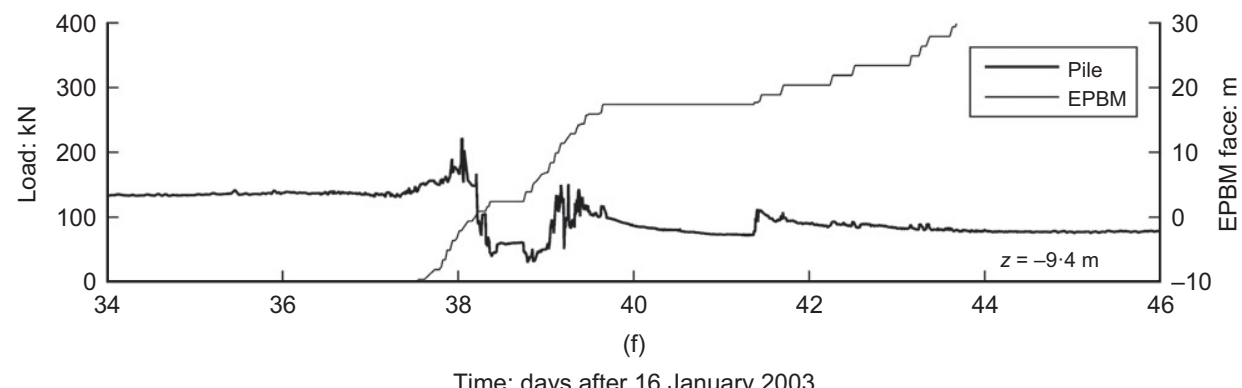

Fig. 10. Changes in the axial load distribution along the length of pile FC due to up-line tunnel construction. Key changes (marked in Fig. 10(d)) as follows: point $O$, initial load distribution prior to tunnelling; point $\mathrm{A}$, load distribution when the EPBM face is beneath the pile; point B, load distribution when the whole tunnelling shield has passed beneath the pile; point $\mathrm{C}$, end of tail grouting behind the shield; point $\mathrm{D}$, final load distribution after tunnelling

load prior to tunnel construction. The face and rear of the EPBM are directly beneath the pile at points A and B, respectively. Point $\mathrm{C}$ denotes the end of tail grouting and point $\mathrm{D}$ corresponds to the final load after tunnel construction.
As the TBM approached pile FC the axial compressive load started to increase gradually at all levels from the EPBM face pressure, with a maximum increase of $120 \mathrm{kN}$ at a pile depth of $z=-5.5 \mathrm{~m}$ (i.e. around the midpoint of the pile length) when the face was directly beneath the pile (point A). 


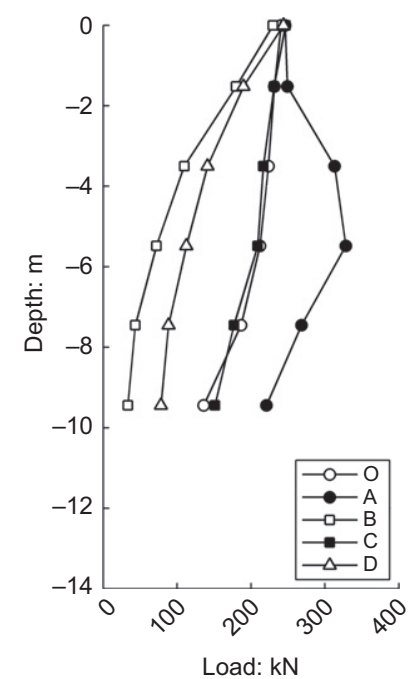

(a)

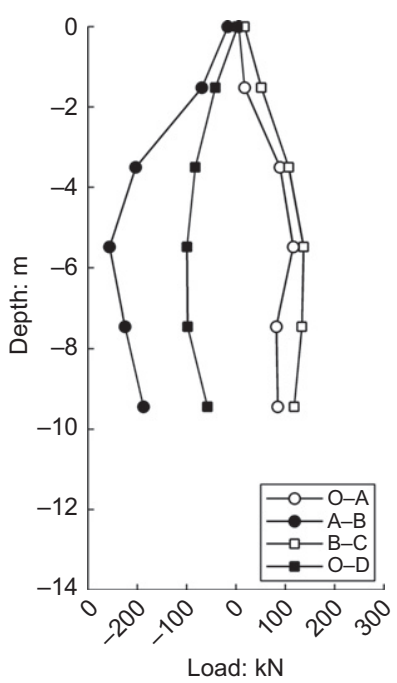

(b)
Fig. 11. (a) Axial load distributions in pile FC for key events during construction of up-line tunnel. (b) Key changes in axial load distributions along pile FC during up-line tunnel construction (points O-D as defined in Fig. 10(d))

Loads then reduced as the EPBM shield passed beneath the pile, which was settling more than the ground over this duration (see Figs 8 and 10). Axial loads remained constant during the $9 \mathrm{~h}$ interruption to tunnelling at $y=2.4 \mathrm{~m}$ but, on recommencement, decreased slightly further until the rear of the EPBM passed beneath the pile (point B, $y=10 \mathrm{~m}$ ). Tail-skin grouting, just after this time, caused another increase in the axial load (point $\mathrm{C}$ ). A gradual reduction in loads (except at the head of the pile) occurred during the $41 \mathrm{~h}$ delay period when the EPBM was stationary at $y=17 \mathrm{~m}$. After another small increase in load, once tunnelling began again, there was a gradual reduction in the axial load with time until steady values were reached after about $y=30 \mathrm{~m}$ (point D).

Reduction in loads before and after tunnel construction were evident at all levels beneath the ground surface, with maximum net changes of about $-100 \mathrm{kN}$ over the middle length of the pile (e.g. $z=-5.5 \mathrm{~m}$ and $-7.5 \mathrm{~m}$; Figs $10(\mathrm{~d})$ and $10(e)$ ). Subsurface measurements broadly corroborate this observation, as discussed later. Overall changes in the axial loads with distance along pile FC at times corresponding to the key events of the up-line tunnel construction are summarised in Fig. 11(a). Curve O shows the initial load distribution prior to tunnelling, with a reduction in load with depth as the $240 \mathrm{kN}$ applied at the head was distributed to the ground by way of shaft friction (this is the same as the actual load shown in Fig. 6(a)).

The effects of the stages of TBM progress and tunnel construction are now described and discussed in terms of pile loads and vertical displacements of the ground (surface and subsurface) and the pile head (with reference to Figs 10 and 11(a)).

(a) The arrival of the EPBM face beneath the pile (point A, at $y=0$ ) induced an axial compressive load of increased magnitude near the middle of the pile. This can be explained in two contexts. First, there was a small differential pile heave at the surface $(<1 \mathrm{~mm}$ relative to the ground, Figs 7(a) and 9(a)), implying that the base of the pile was being pushed upwards (by the face pressure) more than the ground. Secondly, at the same time, the ground surface heaved by $1-2 \mathrm{~mm}$
(Fig. 7(a)), while the ground just above the tunnel (at $z=-14 \mathrm{~m}$ ) heaved by about $5 \mathrm{~mm}$ (Standing \& Selemetas, 2013). Compressive ground strains and stresses generated by these relative displacements would be transmitted to the pile at the ground-shaft interface.

(b) During the passage of the shield beneath the pile (A-B), pile loads reduced very significantly, the final distribution at $\mathrm{B}$ indicating a progressive reduction with depth (Fig. 11(a)). This corresponds to the point when the greatest differential pile settlement at the surface was generated (from about $y=0$ to $4 \mathrm{~m}$, Figs 7(a) and 9(a)), with the pile moving down about $2 \mathrm{~mm}$ more than the ground. Downward displacement of the pile would halt if greater shaft resistance were mobilised along its length. The relative vertical ground displacements generated up to point A increased markedly as the TBM progresses further (to point B). In the made ground and alluvium, there were uniform settlements of about $1 \mathrm{~mm}$ (i.e. negligible vertical strains in these two strata) while just above the tunnel crown (at $z=-14 \mathrm{~m}$ ) the ground heaved by a further $10 \mathrm{~mm}$, as discussed by Standing \& Selemetas (2013). Vertical and lateral ground stresses would increase from the compressive strains induced within it (within the Terrace Gravels and London Clay). As a result, radial stresses on the pile shaft, $\sigma_{\mathrm{r}}^{\prime}$, would increase, thus providing greater shaft capacity (assuming the simple relationship of shaft friction equal to $\sigma_{\mathrm{r}}^{\prime} \tan \delta^{\prime}$, with $\delta^{\prime}$ a constant angle of interface shearing resistance). It is postulated that the increased shaft capacity from this effect would mean that greater amounts of shaft friction could be mobilised, thus progressively reducing pile loads with depth along the pile.

(c) Tail-skin grouting behind the shield (point $\mathrm{C}$ ) induced increases in loads along the length of the pile; these can be attributed to similar reasons for those observed from the effects of the face pressure as the TBM approached the pile. By coincidence, the resulting absolute load distribution at this point was almost identical to the original distribution prior to tunnelling.

(d) The axial load along the pile reduced with time to a steady value (point D), from stress increases from the rapid consolidation that occurred after tunnel construction (Standing \& Selemetas, 2013).

Incremental changes in axial load along the pile length between certain key stages are shown in Fig. 11(b). The final net change in the axial load during tunnel construction (path O-D) is negative in magnitude; that is, a reduction in load was induced in the pile due to tunnel construction with a maximum value of $100 \mathrm{kN}$ over the central length of the pile. As the load at the head of the pile remained constant, this reduction is a result of the combination of differential ground-pile displacements and increased stresses around the pile, allowing greater shaft capacity to be mobilised.

Offset pile FO, $9 \mathrm{~m}$ from the up-line centre-line, initially experienced a very small reduction in axial load as the EPBM face approached the pile $(<10 \mathrm{kN})$, followed by increases in axial load of up to about $50 \mathrm{kN}$ from consolidation of the ground around the pile at this offset. Profiles of the load distribution along the length of the pile before and well after passage of the TBM are shown in Fig. 12.

The response of pile $\mathrm{BC}$ was broadly similar to that of pile FC in that the axial load initially increased as the EPBM face approached the pile and then reduced in magnitude as the shield passed beneath the pile before the base load increased again due to tail grouting. However, significant variations in the load applied at the top of the pile (due to poor control 


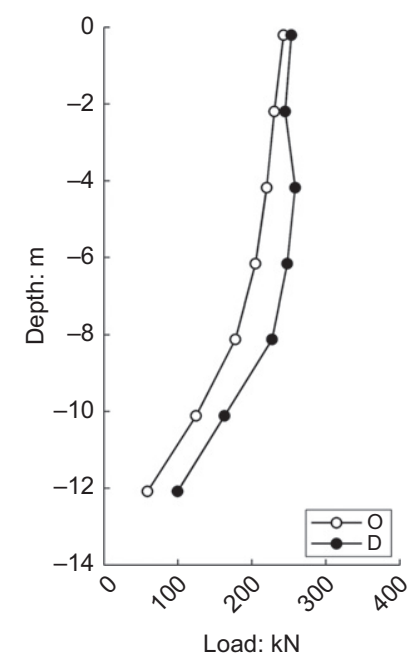

(a)

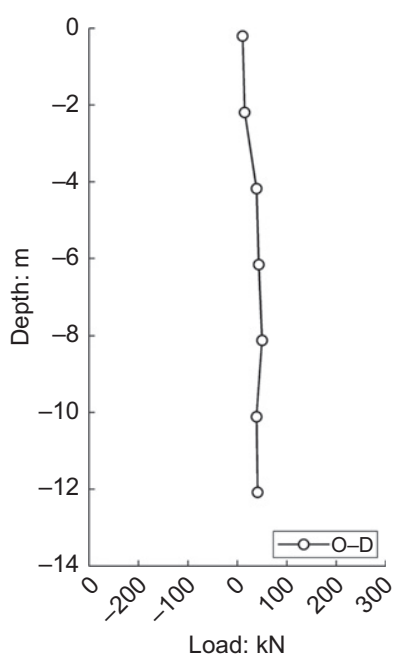

(b)
Fig. 12. (a) Axial load distributions in pile FO prior to and following construction of up-line tunnel. (b) Changes in axial load distribution along pile FO during the up-line tunnel construction. $O$ represents the initial load distribution prior to tunnelling and $D$ denotes the final load distribution after tunnelling

during differential settlement and tail grouting) clearly influenced the axial load response of pile BC.

During the passage of the EPBM shield beneath the pile, the rate of advance of the tunnelling shield was also found to influence the axial load distribution along the pile. When the EPBM face was beneath the pile or a few metres beyond, the axial load remained constant during a pause in the EPBM advance. This was followed by a short abrupt increase in the axial load once tunnelling started again.

Down-line tunnel: pile-load distributions. During construction of the down-line tunnel, the changes in the axial load of all piles were small. Piles FO and BO (at an offset of $7 \mathrm{~m}$ from the down-line tunnel centre-line) showed a small reduction followed by a gradual increase in axial load, bringing the load distribution to values slightly higher than the original. Piles FC and BC (at an offset of $16 \mathrm{~m}$ from the down-line tunnel centre-line) showed a very slight gradual increase in axial loads with time due to negative shaft friction induced by soil movement. This negative shaft friction and subsequent increase in the pile base load with time was slightly larger in magnitude in the case of the longer friction piles FC and FO, as might be expected.

\section{Pile bending moments and deflections due to tunnelling}

Tunnel construction induced small bending moments along the piles in the transverse direction to tunnelling and transiently in the direction of tunnelling. The maximum magnitude of the bending moment measured in pile FO was just over $20 \mathrm{kNm}$ at a depth of $8 \mathrm{~m}$, which corresponds to about $15 \%$ of the ultimate bending capacity of the pile without axial load. In view of the small magnitude of bending moments observed, they are not discussed further here but specific details are provided by Selemetas (2005). In cases where piles are founded below the invert of a tunnel, it is expected that the bending moments induced would be significantly greater and, if the proposed tunnelling works were known of in advance, would govern the reinforcement design of the piles.

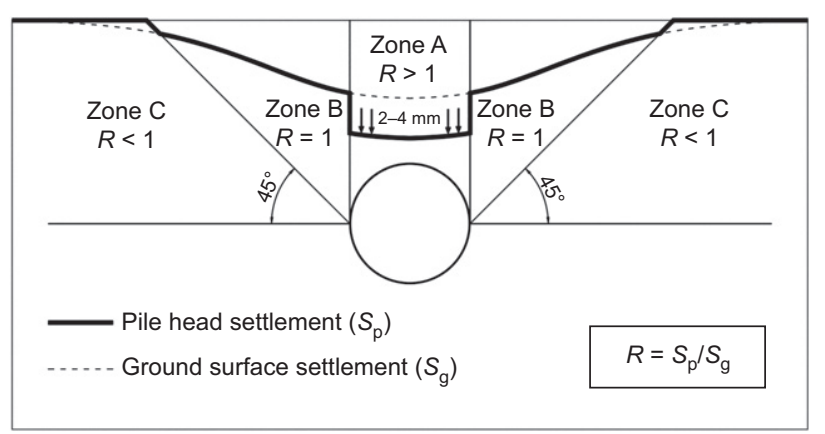

Fig. 13. Zones of influence around an EPBM showing pile settlement relative to ground surface settlement

\section{IMPLICATIONS FOR DESIGN PRACTICE \\ Prediction of pile settlement due to tunnelling}

From the results of this study it is evident that zones develop around an EPBM when tunnelling in London Clay, similar to those presented in previous studies (e.g. Kaalberg et al., 1999; Jacobsz et al., 2001), in which pile head and ground surface settlements can be correlated. In summary and as shown in Fig. 13, piles with their bases located in zone A settled 2-4 mm more than the ground surface $(R>1)$, piles with their bases in zone $\mathrm{B}$ (defined by a line inclined at $45^{\circ}$ between zones $\mathrm{A}$ and $\mathrm{C}$ ) settled by the same amount as the surface $(R=1)$ while piles with their bases in zone $C$ were found to settle less than the surface $(R<1)$. Therefore, for most practical applications, reasonable predictions of pile settlement could be made by using a Gaussian curve as a reference frame. The critical zone is zone A, in which piles are likely to settle more than the ground. This additional settlement is likely to be in the range of 2-4 mm (see Fig. 9) for volume loss values less than $0 \cdot 5 \%$ (as was the case at the research site, as described by Standing \& Selemetas (2013)). In general, the additional settlement would depend on the operation of the EPBM shield, the reduction in the pile base load, the available reserve shaft capacity along the length of the pile, the pile diameter, the soil type and the volume loss.

Pile design for piles subjected to tunnelling-induced movements

A simple assessment of the effects of tunnelling-induced movements on the load distribution in a pile can be made using the framework of Fellenius (1988) and the CemSet method of Fleming (1992). Fig. 14 shows the key load changes for pile FC as presented in Fig. 11(b) (when the EPBM face was beneath the pile and post-tunnelling) compared with the envelope of the theoretical ultimate shaft friction (USF) along the length of the pile, as back-calculated from the CemSet analysis carried out after the pile-loading test. The theoretical shaft friction is plotted both from the head of the pile to the pile toe and from the toe of the pile to the head of the pile, which allows the neutral axis of the pile to be identified at a depth of $9 \mathrm{~m}$. Also shown in Fig. 14 is the mobilised axial load in the pile, $Q_{\mathrm{t}}$, which can be deduced as a function of the relative soil to pile movement for the expanding and contracting displacement fields described by Standing \& Selemetas (2013). The mobilised pile load can be expressed as a function of the shaft stress, $q_{\mathrm{s}}$, with depth, $z$, in the pile using

$$
Q_{\mathrm{t}}=\frac{\delta_{\mathrm{mob}}}{\delta_{\text {limit }}} \pi D \int_{0}^{L} q_{\mathrm{s}} \mathrm{d} z
$$

where $D$ is the pile diameter, $\delta_{\text {mob }}$ is the soil displacement at the pile interface (relative to the pile toe) mobilising positive 


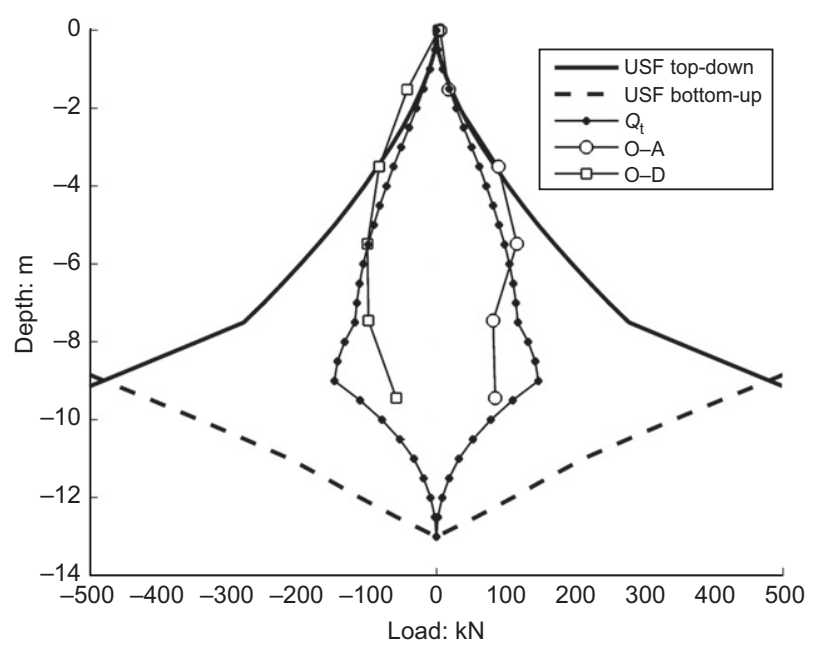

Fig. 14. Tunnelling-induced load changes in a pile compared with the envelope of theoretical load changes based on shaft friction backcalculated during pile tests

or negative shaft friction and $\delta_{\text {limit }}$ is taken as $6 \mathrm{~mm}$ for friction piles (this being a value commonly adopted in practice for piles in clay). Fleming et al. (2009) quote that this value typically varies between $0.5 \%$ and $2 \%$ of the pile diameter for piles in clay. Designers can use equation (1) to predict the likely compressive and tensile loads induced in a pile as a function of the anticipated displacement fields due to tunnelling. Where there is additional compression, the designer should ensure that the allowable compressive stress in the concrete is not exceeded under serviceability conditions. Where tensile stress is induced, the designer must check that the piles are reinforced to the right level, if net tension occurs. From a serviceability perspective, tunnelling-induced pile settlements in friction piles can be adequately controlled by designing piles to have reserve shaft capacity, as demonstrated by the response of pile FC in this case study.

\section{CONCLUSIONS}

Three zones of influence were identified around the EPBM tunnels in London Clay, similar to those presented in previous studies (Kaalberg et al., 1999; Jacobsz et al., 2001 ), in which pile head displacement, $S_{\mathrm{p}}$, and ground surface settlement, $S_{\mathrm{g}}$, can be correlated using $R=S_{\mathrm{p}} / S_{\mathrm{g}}$. Piles with their bases in zone A were shown to settle $2-4 \mathrm{~mm}$ more than the ground surface $(R>1)$. Piles with their bases in zone B (defined by an angle of $45^{\circ}$ between zones A and $C$ ) settled by the same amount as the surface $(R=1)$. Finally, piles with their bases in zone $C$ were found to settle less than the surface $(R<1)$. Therefore, for most practical applications, reasonable predictions of pile settlement can be made by using a Gaussian curve as a 'greenfield' reference frame.

For the case of the observed expanding displacement field (Standing \& Selemetas, 2013), the arrival of the EPBM face beneath a pile located directly above the tunnel induced an axial compressive load of increasing magnitude near the middle of the pile (correlating well with the large compressive strains measured in the ground at that level). During passage of the shield beneath the pile, there was a significant reduction in the axial load (maximum of $200 \mathrm{kN}$ ) induced in the pile, increasing in magnitude with depth, resulting in differential pile settlement relative to the ground. The completion of tail-skin grouting behind the shield again induced a compressive load along the pile, resulting in a load distribution very similar to the original distribution prior to tunnelling. Over time, the axial load reduced along the pile to a steady value. The offset piles experienced increases in their base loads and negative shaft friction, the magnitude of which depended on the offset distances.

A key message from this study is that pile settlement due to tunnelling can be controlled if there is sufficient reserve shaft capacity (as with friction piles FC and FO). However, in the case of end-bearing piles, which have already mobilised their shaft friction, the pile has to move more to compensate for the loss of end-bearing and the remobilisation of the required capacity.

\section{ACKNOWLEDGEMENTS}

The authors would like to acknowledge the support provided by the Engineering and Physical Science Research Council (EPSRC: GR/S05663/01), Mott MacDonald, the Cambridge European Trust and the CTRL Contract 250 consortium joint venture: Edmund Nuttall/Wayss and Freytag/Kier. Many thanks are also due to several researchers at the Cambridge Geotechnical Group and Imperial College for their assistance in taking some of the field measurements described in this paper. This field study would not have been possible without the contributions of Rail Link Engineering and Union Railways (North). The loading frames and control systems were supplied and set up by Precision Measurements and Control, Teesside, UK. Many thanks also go to Cementation Skanska for their continuous support in this research.

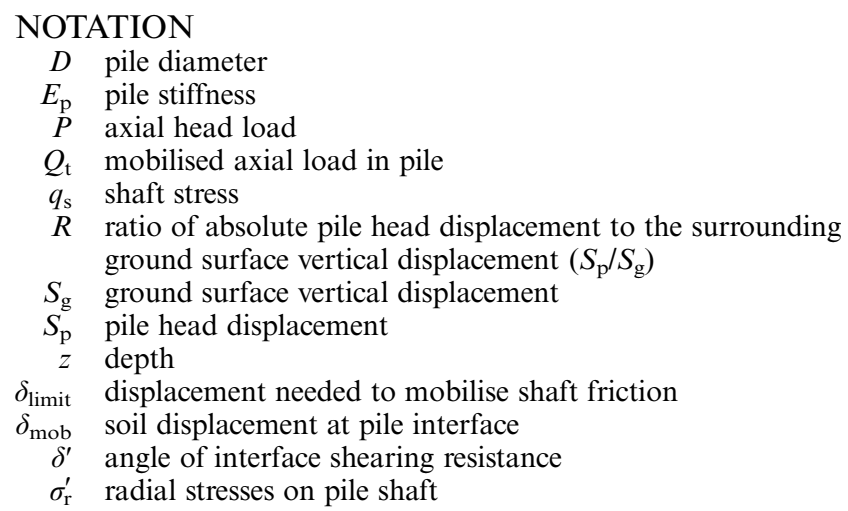

\section{REFERENCES}

Bezuijen, A. \& Van der Schrier, J. S. (1994). The influence of a bored tunnel on pile foundations. Proceedings of centrifuge '94 (eds C. F. Leung, F. H. Lee and T. S. Tan), pp. 681-686. Rotterdam, the Netherlands: Balkema.

BSI (2004). BS EN 1992-1-1: Eurocode 2: Design of concrete structures: general rules and rules for buildings. London, UK: BSI.

Chen, L. T., Poulos, H. G. \& Loganathan, N. (1999). Pile responses caused by tunnelling. J. Geotech. Geoenviron. Engng ASCE 125, No. 3, 207-215.

Coutts, D. R. \& Wang, J. (2000). Monitoring of reinforced concrete piles under horizontal and vertical loads due to tunnelling. In Tunnels and underground structures (eds J. Zhao, J. N. Shirlaw and R. Krishnan), pp. 541-546. Rotterdam, the Netherlands: Balkema.

Fellenius, B. H. (1988). Unified design of piles and pile groups. Transportation Res. Record 1169, 75-83.

Fellenius, B. H. (2004). Unified design of piled foundations with emphasis on settlement analysis. In Honoring George G. Goble-Current practice and future trends in deep foundations 
(eds J. A. DiMaggio and M. H. Hussein), Geotechnical Special Publication no. 125, pp. 253-275. Reston, VA, USA: ASCE.

Fleming, W. G. K. (1992). A new method for single pile settlement prediction and analysis. Géotechnique 42, No. 3, 411-425, http://dx.doi.org/10.1680/geot.1993.43.4.615.

Fleming, W. G. K., Weltman, A. J., Randolph, M. F. \& Elson, W. K. (2009). Piling engineering, 3rd edn. New York, NY, USA: Wiley.

Geilen, T. \& Taylor, G. R. (2001a). The BT building, London Bridge Street. In Building response to tunnelling: case studies from construction of the Jubilee line extension, London, volume 2: case studies (eds J. B. Burland, J. R. Standing and F. M. Jardine), pp. 683-704. London, UK: Thomas Telford.

Geilen, T. \& Taylor, G. R. (2001b). Fielden House, London Bridge Street. In Building response to tunnelling: case studies from construction of the Jubilee line extension, London, volume 2: case studies (eds J. B. Burland, J. R. Standing and F. M. Jardine), pp. 705-726. London, UK: Thomas Telford.

ICE (Institution of Civil Engineers) (2017). Specification for piling and embedded retaining walls, 3rd edn. London, UK: ICE Publishing.

Jacobsz, S. W., Standing, J. R., Mair, R. J., Soga, K., Hagiwara, T. \& Sugiyama, T. (2001). Tunnelling effects on driven piles. In Proceedings of the international conference on response of buildings to excavation-induced ground movements (ed. F. M. Jardine), pp. 337-348. London, UK: CIRIA.

Jacobsz, S. W., Standing, J. R., Mair, R. J., Hagiwara, T. \& Sugiyama, T. (2004). Centrifuge modelling of tunnelling near driven piles. Soils Found. 44, No. 1, 49-56.

Kaalberg, F. J., Lengkeek, H. J. \& Teunissen, E. A. H. (1999). Evaluatie van de meetresultaten van het proefpalenprojek ter plaatse van de tweede Heinenoordtunnel, Technical report R981382. Amsterdam, the Netherlands: Adviesbureau Noord/Zuidlijn (in Dutch).
Loganathan, N., Poulos, H. G. \& Stewart, D. P. (2000). Centrifuge model testing of tunnelling-induced ground and pile deformations. Géotechnique 50, No. 3, 283-294, http://dx.doi. org/10.1680/geot.2000.50.3.283.

Mroueh, H. \& Shahrour, I. (2002). Three-dimensional finite element analysis of the interaction between tunnelling and pile foundations. Int. J. Numer. Analyt. Methods Geomech. 26, No. 3, 217-230.

Pang, C. H., Yong, K. Y. \& Chow, Y. K. (2006). The response of pile foundations subjected to shield tunnelling. In Proceedings of the international conference on geotechnical aspects of underground construction in soft ground (eds K. J. Bakker, A. Bezuijen, W. Broere and E. A. Kwast), pp. 737-743. Leiden, the Netherlands: Taylor \& Francis/Balkema.

Price, G. \& Wardle, I. F. (1983). Recent developments in pile-soil instrumentation systems. In Proceedings of the conference on field measurements in geomechanics (ed. K. Kovari), vol. 1, pp. 2.63-2.73. Rotterdam, the Netherlands: Balkema.

Selemetas, D. (2005). The response of full-scale piles and piled structures to tunnelling. $\mathrm{PhD}$ thesis, University of Cambridge, Cambridge, UK.

Selemetas, D., Standing, J. R., Mair, R. J., Sharrocks, D. M., Parker, F. \& Allen, R. (2002). The response of a piled structure to tunnelling and jacking. In Proceedings of the international conference on geotechnical aspects of underground construction in soft ground (eds R. Kastner, F. Emeriault, D. Dias and A. Gilloux), pp. 367-372. Lyon, France: Spécifique.

Standing, J. R. \& Selemetas, D. (2013). Greenfield response to EPBM tunnelling in London Clay. Géotechnique 63, No. 12, 989-1007, http://dx.doi.org/10.1680/geot.12.P.154.

Vermeer, P. A. \& Bonnier, P. G. (1991). Pile settlements due to tunnelling. In Proceedings of the 10th European conference on soil mechanics and foundation engineering (ed. Associazione Geotechnica Italiana), vol. 2, pp. 869-872. Rotterdam, the Netherlands: Balkema. 